\title{
Climate Change and Global Warming Disclosure Trends in Bangladesh: A Study on Cement and Pharmaceutical \& Chemical Industry
}

\author{
Shafiqul Alam (Corresponding author) \\ Assistant Professor, Department of Business Administration \\ Noakhali Science and Technology University, Noakhali-3814, Bangladesh \\ Tel: 880-16-7364-2243Ｅ-mail: raju13th@gmail.com. \\ Amirus Salat \\ Associate Professor, Department of Accounting and Information Systems \\ University of Dhaka, Dhaka- 1000, Bangladesh
}

SM Nazrul Islam

Associate Professor, Department of Business Administration

Noakhali Science and Technology University, Noakhali-3814, Bangladesh

Abu Syed Jabed

Master of Business Administration, Department of Business Administration

Noakhali Science and Technology University, Noakhali-3814, Bangladesh

Received: December 7, 2019

doi: 10.5296/ijafr.v10i4.17976
Accepted: January 10, 2020 Published: January 17, 2020

URL: https://doi.org/10.5296/ijafr.v10i4.17976

\section{Abstract \\ Purpose}

The core objective of the study is to critically examine the trends of the climate change \& global warming discourses and their dominant characteristics in developing country 
perspective like Bangladesh.

\section{Design/Methodology}

This paper extends the current literature by considering reporting practices of corporation in developing country perspective. Using a sample of 30 listed companies from two major emission intensive industries, we conducted a content analysis for a span of 5 years from 2015 to 2019. A data set consisting of 19 issues of climate change and global warming information was developed through literature review.

\section{Findings}

Although the study observes generally adapting increased disclosures over time, sample companies' disclosures are lagging. This analysis provides the comprehension of below average climate change and global warming disclosure practices by the companies. Showed positive attitude to disclosing on climate change and global warming in terms of both number of issues disclosed and number of sample companies disclosed, only a few companies disclose rigorously in their annual reports. Compared to Bangladeshi companies, multinational companies are more inclined to comply environmental regulations and disclose more climate change and global warming issues. In particular, we improve the prior literature by focusing on voluntary climate change disclosures and by developing a content analysis to assess the extent of climate change disclosures by polluting industries in Bangladesh.

Keywords: Climate change \& global warming disclosures, Dhaka \& Chittagong Stock Exchange, Emission intensive industries

\section{Introduction}

One of the recent developments in the arena of social and environmental accounting is the issue of climate change and global warming. Global warming as an international environmental issue is getting ample importance from the part of the different stakeholders. The main reason for global warming is the emission of greenhouse gases (GHG) like carbon dioxide, methane and other gases from different sources. Media, global leaders, environmentalists, customers, investors and the other stakeholders are considering this issue seriously. As a result, companies face a lot of challenges in order to prove that they are careful about the environmental pollution and are performing in a responsible manner in this context. It is not enough for the companies just to perform their responsibilities in respect to global warming but they should also inform it to the stakeholders in order to maintain good public relations. Over last few decades, companies almost all around the world have developed a tendency to report on their environmental performances. In most of the cases, they disclose such kind of information voluntarily and mainly in non-quantitative form. Companies use words and statements to express their stands on the environmental issues. They use languages in these statements and thus these statements represent socially constructed meanings. Widdowson (2007: XV) mentioned that 'meanings are socio-cultural constructs of reality: they represent particular beliefs and values that define ways of thinking about the world'. As a result, we can say that the company statements on environmental issues represent their beliefs, values and motives. 


\section{Mll Macrothink}

International Journal of Accounting and Financial Reporting

ISSN 2162-3082

2020, Vol. 10, No. 4

Bangladesh is a developing country and thus the companies here are not under strict monitoring for GHG emission issues. Despite the absence of close monitoring, some companies are voluntarily disclosing on their stance regarding climate change and global warming issues in the annual reports. 'One of the reasons is the adoption of western-styled models in emerging economies that were promoted by attempts by governments and policy makers to gain legitimacy with external stakeholders such as international aid agencies and foreign governments' (Khan, Muttakin and Siddiqui, 2013: 210).

Research on climate change and global warming related disclosure is still in its elementary form in Bangladesh. This paper comes with the question of emission incentive industries' GHG disclosures in Bangladesh. $\mathbf{C O}_{2}$ emissions per capita in Bangladesh are equivalent to $\mathbf{0 . 4 7}$ tons per person (based on a population of 157,977,153 in 2016), an increase by $\mathbf{0 . 0 2}$ over the figure of $0.46 \mathrm{CO}_{2}$ tons per person registered in 2015; this represents a change of 3.4\% in $\mathrm{CO}_{2}$ emissions per capita (Worldometer). Pharmaceutical \& Chemical and Cement industries are the two major contributors of GHG emission. These two industries have been selected because burning of coal, natural gas, and oil for electricity and heat production produces a large amount of greenhouse gas. As a result, we pick these two industries as our sample to find out the extent of disclosures. To achieve the research objective, we conduct a discourse analysis of the corporate reporting of pharmaceutical \& chemical and cement industries on climate change and global warming issues. Through a content analysis of the annual reports of 30 companies listed in Dhaka Stock Exchange or Chittagong Stock Exchange, the paper attempts to highlight the climate change \& global warming discourses and their dominant characteristics.

The results of our study are presented here briefly. We find that overall result of reporting of climate change by two emission intensive industries in Bangladesh is lagging. The analysis provides the comprehension of below average climate change and global warming disclosure practices by two most emission intensive industries. Our results are consistent with the prediction of negative association arising from socio-political theory such as stakeholder theory and legitimacy theory. We improve the prior literature in way that we tried to relate voluntary disclosure theory particularly legitimacy theory in developing country perspective.

The remainder of the paper is organized as follows. Section 2 addresses the significance of climate change issues for Bangladesh. Section 3 reviews previous literature on the disclosures on climate change issues and identifies the research gap. In the next one we outline research design followed by the discussion of our analyses and findings. Finally, the last section presents our conclusions, recommendations, and limitations.

\section{Climate Change and Bangladesh}

Bangladesh is one of the most climate vulnerable countries in the world and will become more so as a result of climate change (MoEF, 2009). Climate change is imposing a deal of great threats to the residents, ecological balances and living environments of Bangladesh, a developing country which has just touched the recognition of lower-middle income (World Bank, 2015b). Millions of people are suffering because of climate change and each year handsome numbers of people are being added to the list. Because of climate change and global warming, sea level rise in the coming decades will create over 25 million climate refugees (DoE, 2007). This is twice the entire population of the Netherlands (DoE, 2007). 
According to Ministry of Planning (2016), about $13 \%$ of the households and $12.64 \%$ of the population live in the disaster-prone area and are being affected by climate change. In 2015, Bangladesh Bureau of Statistics reported that Bangladesh suffered a financial loss of $\$ 2.33$ billion because of natural calamities for which climate change is directly responsible (Ministry of Planning, 2016).

Climate change in Bangladesh is demonstrating its ravaged expressions by means of lower crop yields, higher sea levels, frequent floods, more intense cyclones and tornadoes, extreme rainfall, droughts, salinity, extreme fog and cold waves etc. (World Bank, 2014). Floods are frequently visiting in Bangladesh. According to the report of International Federation of Red Cross and Red Crescent Societies (2014), by the flood of August of 2014, around 2.8 million people were affected. According to Inter-governmental Panel on Climate Change (IPCC) (2007), the sea level may rise by $31 \mathrm{~cm}$ to $71 \mathrm{~cm}$ by 2100 . In case of Bangladesh, the sea level may rise even by larger figure. IPCC forecasts that the sea level of Bay of Bengal can rise by $0.2 \mathrm{~m}$ to $1 \mathrm{~m}$ by 2100 . In 2008, Bangladesh Water Development Board found that at Hiron Point of Sundarban, the sea level rose by $5.6 \mathrm{~mm}$ (The Daily Star, 2013). Southeast coastal areas will be severely affected by increasing river salinity which will lead to shortages of drinking water, irrigation and impose a major threat to the aquatic systems. Cropping yield in the coastal area is under great intimidation for the soil salinity and it is anticipated that yield of rice will decline $15.6 \%$ by 2050 (World Bank, 2015a).

Industries greatly rely on the burning fossil fuels for production. Business sector is one of the main responsible parties for global warming and climate change. Since last decade, activities of the business are getting monitored by several stakeholders like the government, social parties, media and others. Especially after the agreement naming the Kyoto Protocol in 1997 signed by almost 175 countries, business organizations are constantly facing pressure from the part of different stakeholders (Ahmad \& Hossain, 2015). The Bangladesh Climate Change Strategy and Action Plan (MoEF, 2009) notes the involvement of the private and business sector in meeting the challenges of climate change. In this context, the extent and nature of actual responses in relation to climate changes of business firms can be examined.

\section{Related Prior Periods Work}

The issue of corporate environmental disclosure is nowadays a very common issue in the social and environmental accounting literature. For many years various studies have been conducted worldwide on climate change and global warming issue that has unlocked newer avenues for social and environmental accounting researchers (Ahmad \& Hossain, 2015). Climate change is an issue that calls for a corporate response as climate change significantly impacts business operations. One of the main future risks to business and society is the consequences of climate change (ACCA, 2007). As the impacts of climate change become increasingly severe and perceptible, corporations that continue to disregard the risks created by the earth's shifting climate stand to suffer significant financial harm (Wasim, 2019). The issues like climate change and global warming have influenced both 'climate science and climate policies'. Researchers have found some major reasons for global warming is the emission of greenhouse gases (GHG) like chlorofluorocarbons (CFC), carbon dioxide, methane and other gases from different sources. UNEP and UNFCCC (2002) mentioned that human activities are the main reasons for GHG emission and the main human activities that 
add in global warming include burning of fossil fuels, cutting and burning the trees in the forest.

To hold businesses accountable for climate change performance, corporate climate change disclosure has increased substantially over the last decade (Amran et al., 2019). Climate change disclosure by the corporation is still an under-researched area (Ahmad \& Hossain, 2015). Dey et al. (2017) found that the level of climate change disclosure is positively correlated with the size of the disclosing companies. Large companies are disclosing more climate change related information in their annual reports in order to legitimate their position in the market. Kilic and Kuzey (2019) studied on Turkish banking industry and found the significant and positive impacts of bank size, profitability, bank age and listing status upon the extent of the climate change disclosures. Ahmad and Hossain (2015) considered the institutional investors as a powerful stakeholder who are aware of this issue. Though the investors demanding more information from companies about their vulnerabilities to climate change, there is virtually no discussion of climate change risks in publicly traded companies' filings with the Securities and Exchange Commission and on other public platforms (Wasim 2019). Nurunnabi (2015) found that lack of regulation and a culture of low social accountability among the companies contribute to a low level of disclosure.

Most of the researchers on the climate change issues, especially on carbon accounting, are based on developed countries (Stechemesser \& Guenther, 2012). Developing or less developed countries, as well as the Asian countries got less importance from the researchers (Ahmad \& Hossain, 2015). Belal et al. (2010) studied on Bangladesh and found that the level of environmental and climate change disclosures in annual report and website is very low in Bangladesh. Only few companies made disclosures in the specific areas of climate change but interestingly they popularly disclose adaptation measures. The nature of disclosures is mostly positive and descriptive. Luo et al. (2013) studied on both developed and developing countries in order to make a comparison between their carbon disclosure patterns. Bangladeshi companies have been adopting environmental reporting practices voluntarily in recent years (Ahmad, 2012). However, it is not clear that what factors motivate the companies to disclose environmental information and what are the perceptions of stakeholders regarding the reporting practices of the companies in Bangladesh. The Company Act 1994 and the Bangladesh Chartered Accountants Order 1973, other relevant laws prescribed by the Securities and Exchange Commission Rules 1987 and the Income Tax Ordinance-1984 do not prescribe any periodical mandatory environmental disclosure by the companies (Ahmad, 2012). The researchers showed that no international standard is exclusively dedicated to environmental information, but environmental issues are mentioned in several standards and interpretations. They directly or indirectly deal with the reorganization, measurement and disclosure of environmental expenses, assets and liabilities. In an increasingly carbon constrained world, it is expected that organizations will disclose their policies and procedures pertaining to carbon emission and climate change in a comprehensive, transparent, and accountable manner. In this regard, one way of corporate responses might be the systematic measurement and reporting of their environmental and climate change impact (Hopwood, 2009).

As we have considered the emergent impact of climate change, more specific accounting and 
reporting standards have been developed, e.g., Climate Disclosure Standards Board (CDSB)'s Climate Change Reporting Framework (CCRF), Greenhouse Gas (GHG) Protocol Corporate Accounting \& Reporting Standard, GHG Protocol Corporate Value Chain Accounting \& Reporting Standard, and GHG Protocol Product Life Cycle Accounting \& Reporting Standard. These standards mainly aim at eliciting information to stakeholders on how climate change affects the strategy, performance and prospect of organization through disclosure of GHG emissions, climate change mitigation, adaptation measures etc. (Dey et al., 2017).

Government of Bangladesh $(\mathrm{GoB})$ has recently enacted very important laws regarding environment such as the Bangladesh Environment Conservation Act, 1995 (hereafter the Act), and the Environment Conservation Rules, 1997. Under the Act, companies may be asked to disclose environmental information as and when required. Moreover, the Act, requires, environmental clearance from the Ministry of Environment and Forest before the establishment of a new industrial plant. There is an increasing demand from various stakeholder groups for companies to publicly report information about their climate change-related business practices (Global Reporting Initiative 2007). Wasim (2019) suggested that by encouraging companies to assess and disclose climate change risks, the lawsuits not only emphasize on maintaining transparency and efficiency in financial markets but also may spur innovation and new modes of thinking that can help mitigate the harmful impacts of climate change.

From the review of prior literature presented above, we see that there is a minimal, but growing, academic research investigating corporations' climate change-related disclosure practices within the Bangladesh context. Specifically, there is a complete absence of a study that investigates how emission intensive industries particularly cement and chemical, disclose the GHG and climate issues. Based on the literature gap, we try to address the issue of legitimacy of two major emission intensive industries in Bangladesh to report the climate change issues to the stakeholders.

\section{Methodology of the Study}

\subsection{Sample Selection and Data Collection}

The main objective of the study is to critically examine the climate change and global warming disclosure practices of the listed pharmaceutical $\&$ chemical and cement companies in Bangladesh. Pharmaceutical \& chemical and cement sectors have been selected purposively as a sample from the available sectors which are listed in both Dhaka Stock Exchange (DSE) and Chittagong Stock Exchange (CSE) to conform to the objective of the study.

Table 1. Sample companies for the study

\begin{tabular}{llll}
\hline & \multicolumn{3}{c}{ Pharmaceutical \& Chemical Industry } \\
\hline No. & \multicolumn{1}{c}{ Bangladeshi Companies } & No. & \multicolumn{1}{c}{ Multinational Companies } \\
\hline 1 & ACI Formulations Ltd. & 20 & Advanced Chemical Industries Ltd. \\
\hline 2 & The ACME Laboratories Ltd. & 21 & Berger Paints Bangladesh Ltd. \\
\hline 3 & BEXIMCO Synthetics Ltd. & 22 & Marico Bangladesh Ltd. \\
\hline 4 & Renata Ltd. & 23 & Reckitt Benckiser (Bd.) Ltd. \\
\hline
\end{tabular}


$5 \quad$ FAR Chemical Industries Ltd.

24

GlaxoSmithKline (GSK) Bangladesh Ltd.

\begin{tabular}{ll}
\hline 6 & AFC Agro Biotech Ltd. \\
\hline 7 & Active Fine Chemicals Ltd. \\
\hline 8 & BEACON Pharmaceuticals Ltd. \\
\hline 9 & BEXIMCO Pharmaceuticals Ltd. \\
\hline 10 & Central Pharmaceuticals Ltd. \\
\hline 11 & GLOBAL Heavy Chemicals Ltd. \\
\hline 12 & The IBN SINA Pharmaceutical \\
\hline 13 & Imdustry Ltd. \\
\hline 14 & Kohinoor Chemical Company Ltd. \\
\hline 15 & Orion Infusion Ltd. \\
\hline 16 & Orion Pharma Ltd. \\
\hline 17 & Pharma Aids Ltd. \\
\hline 18 & Salvo Chemical Industries Ltd. \\
\hline 19 & Square Pharmaceuticals Ltd. \\
\hline
\end{tabular}

\begin{tabular}{llll}
\hline \multicolumn{4}{c}{ Cement Industry } \\
\hline No. & \multicolumn{1}{c}{ Bangladeshi Companies } & No. & Multinational Companies \\
\hline 1 & MI Cement Factory Ltd. & 5 & Lafarge Surma Cement Ltd. \\
\hline 2 & Confidence Cement Ltd. & 6 & Heidelberg Cement Bangladesh Ltd. \\
\hline 3 & Premier Cement Mills Ltd. & & \\
\hline 4 & Meghna Cement Mills Ltd. & & \\
\hline
\end{tabular}

There are 32 pharmaceutical \& chemical companies and 7 cement companies listed in both DSE and CSE. Out of them 24 pharmaceutical \& chemical companies and 6 cement companies have been selected for this study as the annual reports of the others aren't available in online. The study was conducted in 2020 . To make the study a contemporary and up to date, we collected data from the annual reports for the latest years. Therefore, 150 annual reports of the 30 sample companies (last 5 years annual reports) were collected. At this moment of analysis only two companies (Lafarge Surma Cement Ltd. \& Heidelberg Cement Bangladesh Ltd.) haven't published their annual report of 2019 and hence 2018 annual report is considered as the latest of them. The 2018-19 annual report will be the latest for the rest 28 companies. To analyze in a convenient way, we consider the earliest period 'Year 1' and the latest period as the 'Year 5' consecutively (Annexure 1).

\subsection{Content Analysis}

A manual content analysis approach was followed in analyzing the annual reports to measure the volume of climate change and global warming information disclosure. 
Table 2. Climate change and global warming disclosures index

\begin{tabular}{ll}
\hline No. & \multicolumn{1}{c}{ Disclosure issues } \\
\hline 1 & $\begin{array}{l}\text { Organization has a separate environment, health and safety plan and it discloses in the } \\
\text { publicly available documents. }\end{array}$ \\
\hline 2 & $\begin{array}{l}\text { Anything mentioned about the climate change or global warming in the chairman's } \\
\text { statement/CEO/Directors report in the annual report. }\end{array}$ \\
\hline 3 & $\begin{array}{l}\text { Anything mentioned about the environment in the chairman's } \\
\text { statement/CEO/Directors report in the annual report (General Concern) }\end{array}$ \\
\hline 4 & Policy to develop alternative/ renewable energy. \\
\hline 5 & Energy consumption in the operation. \\
\hline 6 & Management approach for energy saving and efficiency. \\
\hline 8 & Management approach for raw materials. \\
\hline $\begin{array}{l}\text { Management approach for } \\
\text { ii. Effluents management \& }\end{array}$ \\
\hline 10 & Mention anything about the biodiversity. \\
\hline 11 & Preserving biodiversity \\
\hline 12 & $\begin{array}{l}\text { Management approach for emissions of } \\
\text { i. GHG/CO } 2 \\
\text { ii. ODS \& } \\
\text { iii. Numeral data on gas emission. }\end{array}$ \\
\hline
\end{tabular}

\begin{tabular}{ll}
\hline 13 & $\begin{array}{l}\text { The organization has policy to comply with GRI guidelines, GHG Protocol standard } \\
\text { or any other voluntary standards (reporting benchmark) }\end{array}$ \\
\hline 14 & Tree plantation \\
\hline 15 & $\begin{array}{l}\text { Significant impact of activities, products \& services on climate change \& global } \\
\text { warming }\end{array}$ \\
\hline 16 & $\begin{array}{l}\text { Is there any separate section is devoted to climate change and/or global warming } \\
\text { (General Concern)? }\end{array}$ \\
\hline 17 & $\begin{array}{l}\text { Do they have any specific board committee related to environment and/or climate } \\
\text { change? }\end{array}$ \\
\hline 18 & Compliance with environmental laws and regulations \\
\hline 19 & Anything about Kyoto protocol and/or Paris Agreement. (General concerns). \\
\hline
\end{tabular}

A data set consisting of 19 issues of climate change and global warming information was developed through literature review. The data set of 19 items was collected from the study of Ahmad \& Hossain (2015), Belal, et al. (2010), Dey, et al. (2017) and others. Table 2 presents the 19 issues (including 2 sub-issues in $8^{\text {th }}$ issue and 3 sub-issues in $12^{\text {th }}$ issue) that have used in our analysis to make the content analysis. Although the analysis of the study is mainly based on 19 issues, to simplify the analysis of the study we consider in total 22 issues considering the sub-issues under two issues. 


\section{Mll Macrothink}

International Journal of Accounting and Financial Reporting

ISSN 2162-3082

2020, Vol. 10, No. 4

\section{Analysis and Results}

\subsection{Disclosure Overview}

This section deals with the analysis of nature and extent of the climate change \& global warming disclosures by the sample pharmaceutical \& chemical and cement companies of Bangladesh and figures out the findings linked with current practices. The study found that $87 \%$ of the total sample companies (total of pharmaceutical \& chemical and cement companies) disclosed climate change \& global warming issues in at least one item or category in their last five years annual reports. $13 \%$ of the sample companies didn't disclose any issue on climate change $\&$ global warming.

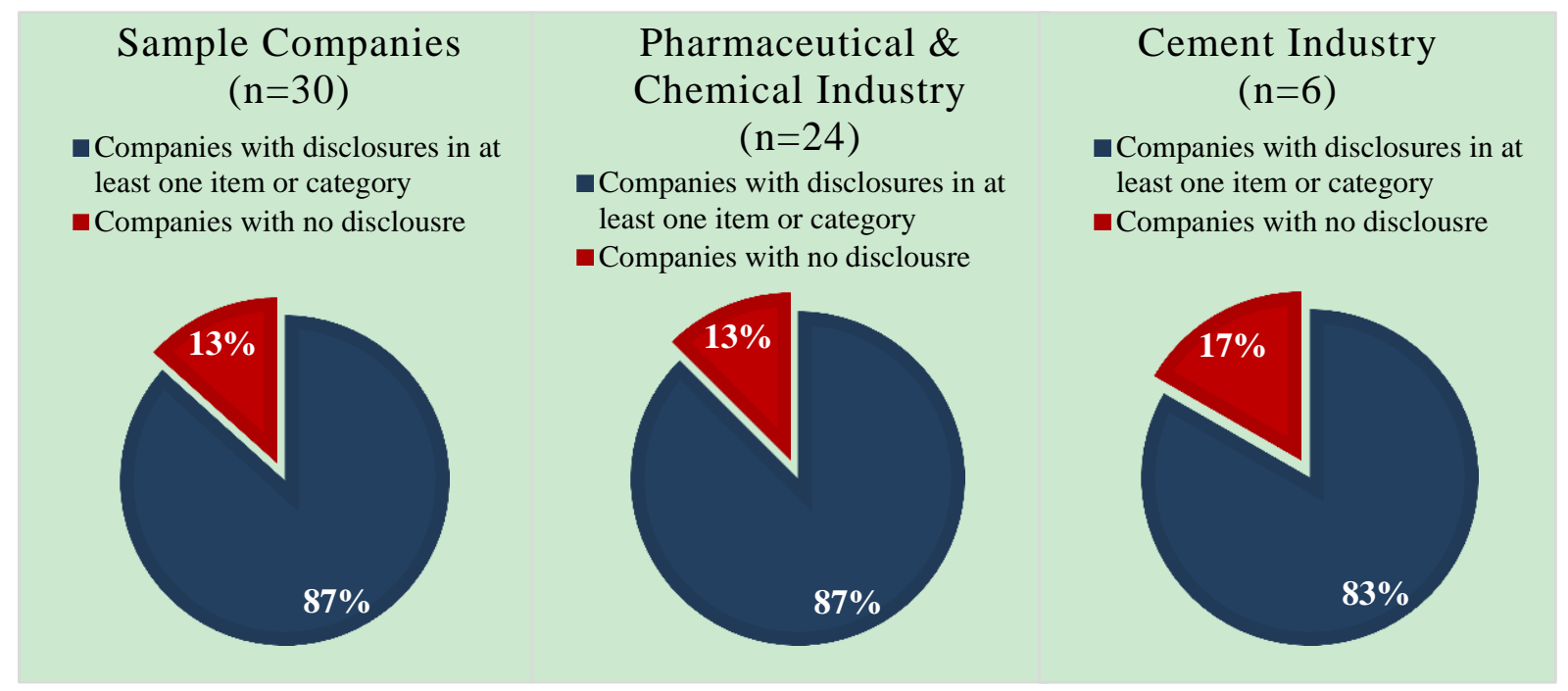

Figure 1. Overall climate change \& global warming disclosure and industry wise disclosure comparison

Although it is observed from the above figure that disclosure performance is better in pharmaceutical \& chemical industry as $87 \%$ of the sample pharmaceutical \& chemical companies disclosed climate change $\&$ global warming issues in at least one item or category than that of cement industry as $83 \%$ of the sample cement companies disclosed at least one item or category in their last five annual reports, from the below analyses we can construe that the climate change disclosure practices by the companies are not generally satisfactory. 


\section{I Macrothink \\ International Journal of Accounting and Financial Reporting

\subsection{Companies' Yearly Disclosure Rate}

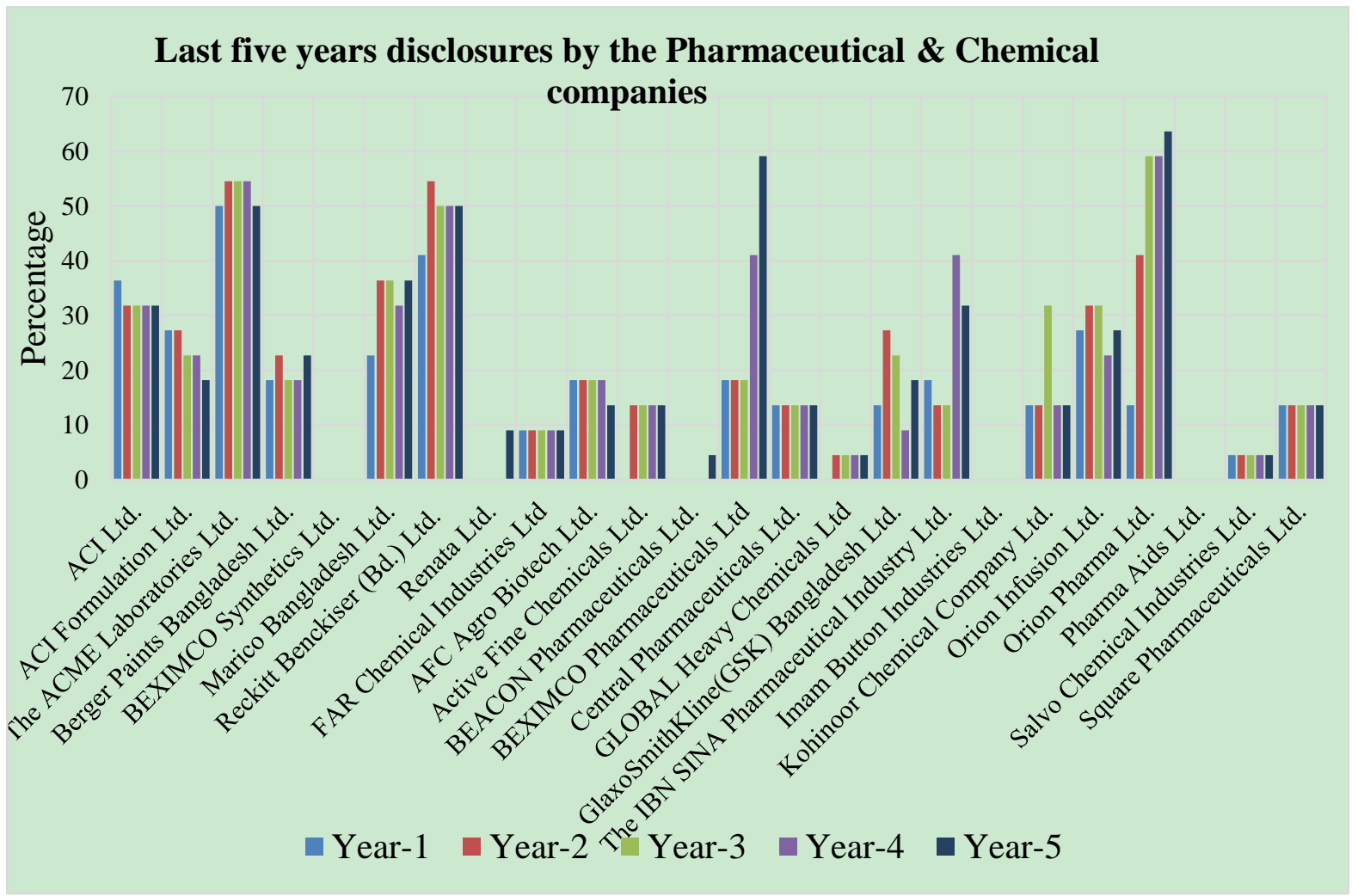

Figure 2. Percentage of last five years disclosures in the annual report of Pharmaceutical \&

Chemical companies (Annexure 2B)

This figure shows that BEXIMCO Synthetics Ltd., Imam Button Industries Ltd. \& Pharma Aids Ltd. disclosed not a single issue. Whereas the vertical line for The ACME Laboratories Ltd., Reckitt Benckiser (Bd.) Ltd. and Kohinoor Chemical Company Ltd. is at first upward and then again, it's downward. Disclosure rate is downward for ACI Formulations Ltd. whereas disclosure rate is upward for BEXIMCO Pharmaceuticals Ltd. \& Orion Pharma Ltd. over the sample years. From the above figure we also observe that some companies' disclosure rates remain static and some companies' disclosure rates are fluctuating in the annual reports over the last five years. There are two companies such as Renata Ltd. \& BEACON Pharmaceuticals Ltd. who were not in the disclosure practice earlier started disclosing some issues related to climate change and global warming in their latest annual report which indicates that day by day companies are becoming concern on climate change and global warming when conducting their business operation. 


\section{Macrothink}

International Journal of Accounting and Financial Reporting

ISSN 2162-3082 2020, Vol. 10, No. 4

\section{Last five years disclosures by the Cement companies}

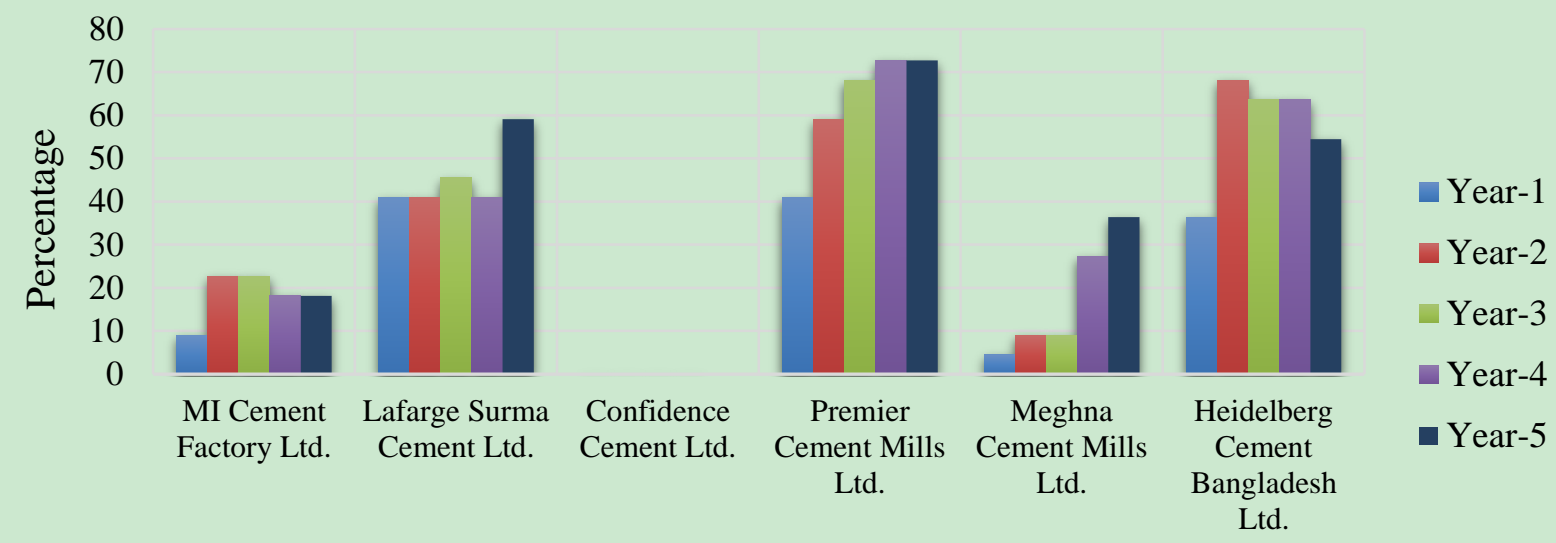

Company Name

Figure 3. Percentage of last five years disclosures in the annual report of cement companies.

(Annexure 2B)

Figure 3 exhibits that there is no vertical line for Confidence Cement Ltd. as this company disclosed not a single issue whereas disclosure rate is at first upward and then again, it's downward for MI Cement Factory Ltd. and Heidelberg Cement Bangladesh Ltd. The remaining companies such as Lafarge Surma Cement Ltd., Premier Cement Mills Ltd. and Meghna Cement Mills Ltd. showed their upward tendency to disclose the climate change and global warming issues over the last five years.

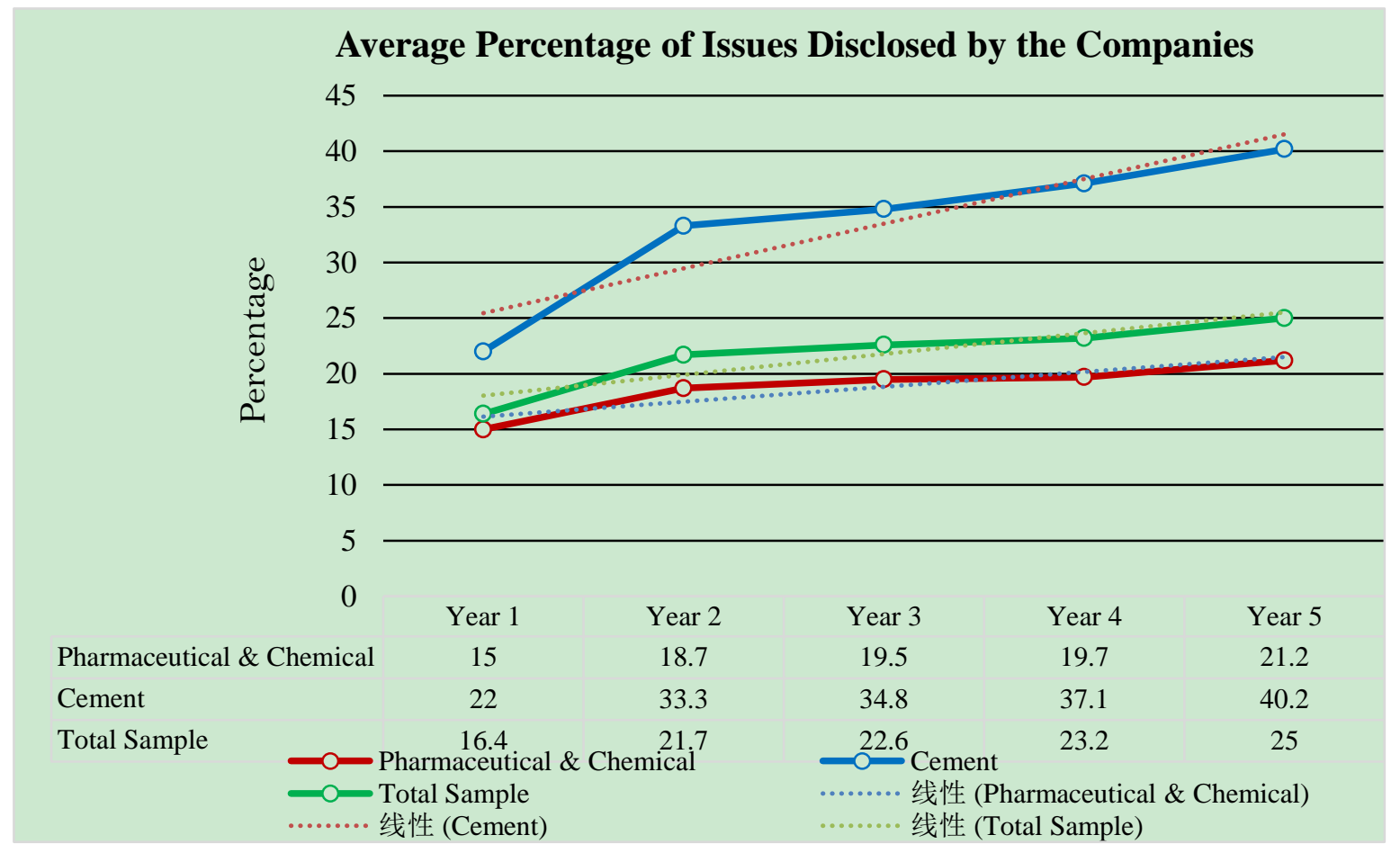

Figure 4. Percentage of average issues disclosed in last five years (Annexure 2B)

Figure 4 illustrates that average $16.4 \%$ of climate change and global warming issues were disclosed by total sample companies in the first year which is gradually increasing in the 


\section{MIN Macrothink}

International Journal of Accounting and Financial Reporting

ISSN 2162-3082

following years after the first year and it became $25 \%$ in the final year. This figure also shows that disclosure performance by cement companies is quite better compared with pharmaceutical \& chemical companies. In each of the last five years disclosure rate (average percentage of issues disclosed) by cement companies is higher than that of pharmaceutical \& chemical companies though both the industries disclosure trend is upward year to year. This practice will help them to reduce the effect of activities, products and services to the climate change and global warming.

\subsection{Number of Disclosing Companies}

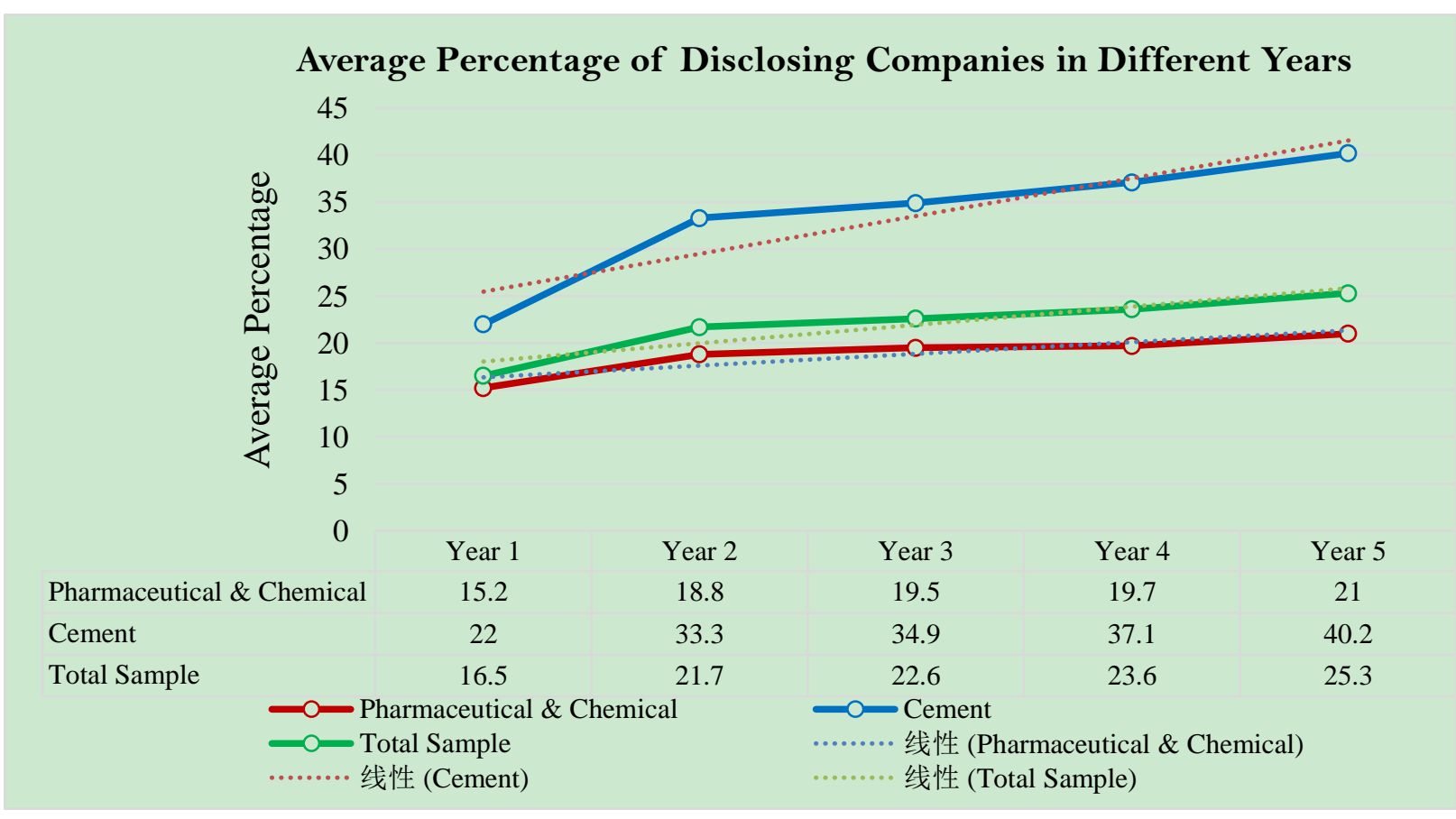

Figure 5. Average percentage of disclosing companies in last five years. (Annexure 3)

This figure exhibits that average $16.5 \%$ of the total sample companies disclosed at least one item or category of climate change and global warming issues in the first year which is raised to $25.3 \%$ in the latest year. Average percentage of disclosing companies for both pharmaceutical \& chemical and cement companies is increasing year to year. The cement industry is in the leading position as the number of disclosing companies is higher at this industry in all the last five years than that of the pharmaceutical \& chemical industry (Annexure 3). This is very much satisfactory that year to year the companies are increasing the disclosure of climate change and global warming issues and new companies are engaging in disclosure practices which didn't do that before. 


\section{$\triangle$ Macrothink}

\subsection{Number of Sentences Disclosed}

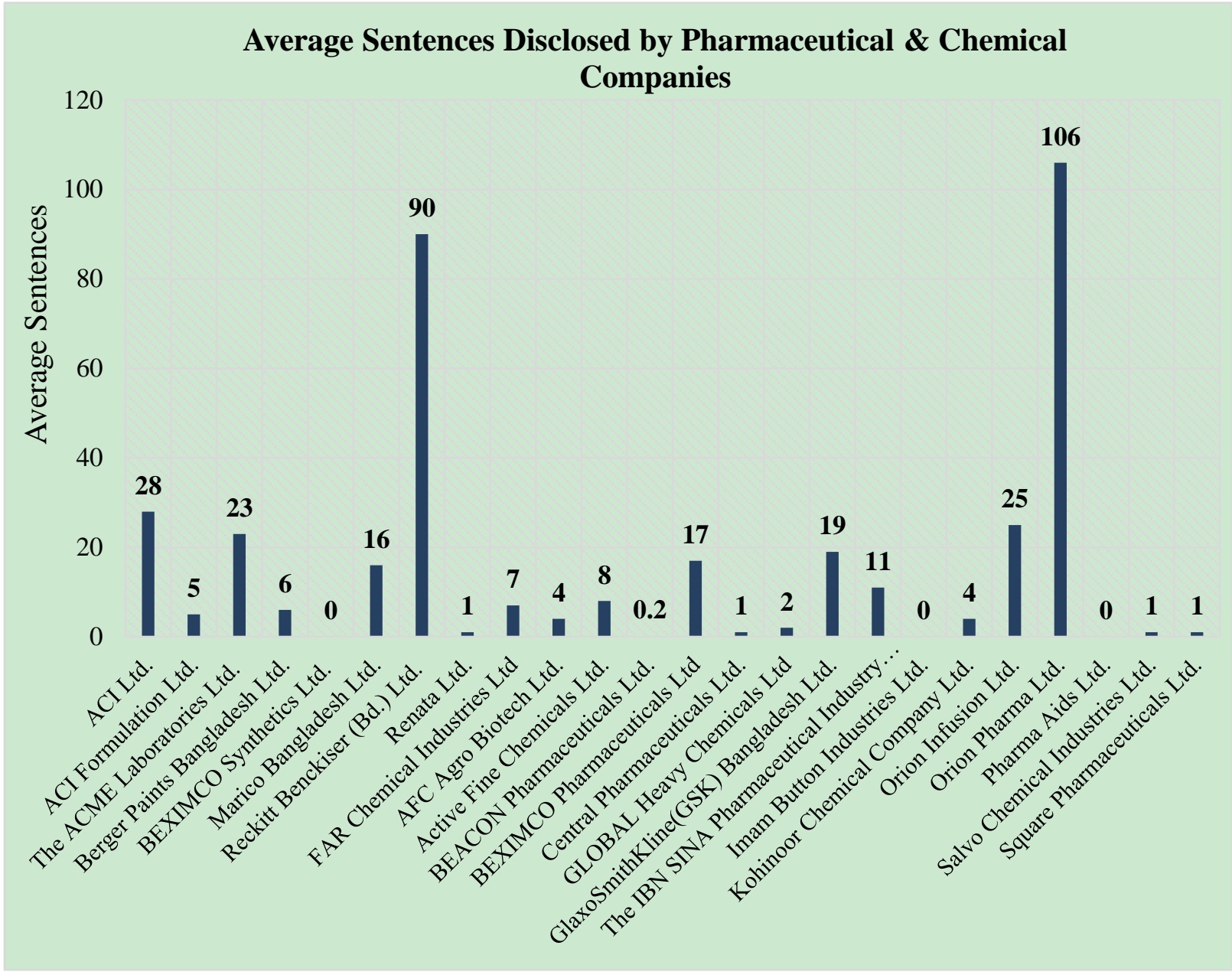

Figure 6. Average sentences disclosed by individual Pharmaceutical \& Chemical companies in the last five years (Annexure 4A)

The number of sentences disclosed by the companies of pharmaceutical \& chemical and cement industry in their annual reports has been shown separately. Figure 6 presents the average sentences disclosure information by the companies of pharmaceuticals $\&$ chemical. It shows that BEXIMCO Synthetics Ltd., Imam Button Industries Ltd. \& Pharma Aids Ltd. disclosed nothing about climate change and global warming issues. The Figure also shows that half of the sample pharmaceutical \& chemical companies (12 companies) disclosed between 1 to 10 sentences in their last five years annual reports. The ACME Laboratories Ltd. disclosed average 23 sentences, average 16 sentences are disclosed by Marico Bangladesh Ltd., average 17 sentences by BEXIMCO Pharmaceuticals Ltd., 19 sentences by GlaxoSmithKline (GSK) Bangladesh Ltd., 11 sentences by The IBN SINA Pharmaceutical Industry Ltd. and Orion Infusion Ltd. disclosed average 25 sentences in each year over the last five years. These six companies are considered as mediocre because of reporting 11 to 25 sentences. The highest average 106 sentences have been disclosed by Orion Pharma Ltd. 


\section{MInstitute ${ }^{\text {Mink }}$}

International Journal of Accounting and Financial Reporting

ISSN 2162-3082

followed by Reckitt Benckiser (Bd.) Ltd. and Advanced Chemical Industries (ACI) Ltd. disclosed average 90 sentences and 28 sentences consecutively. They disclosed rigorously on different climate change \& global warming issues.

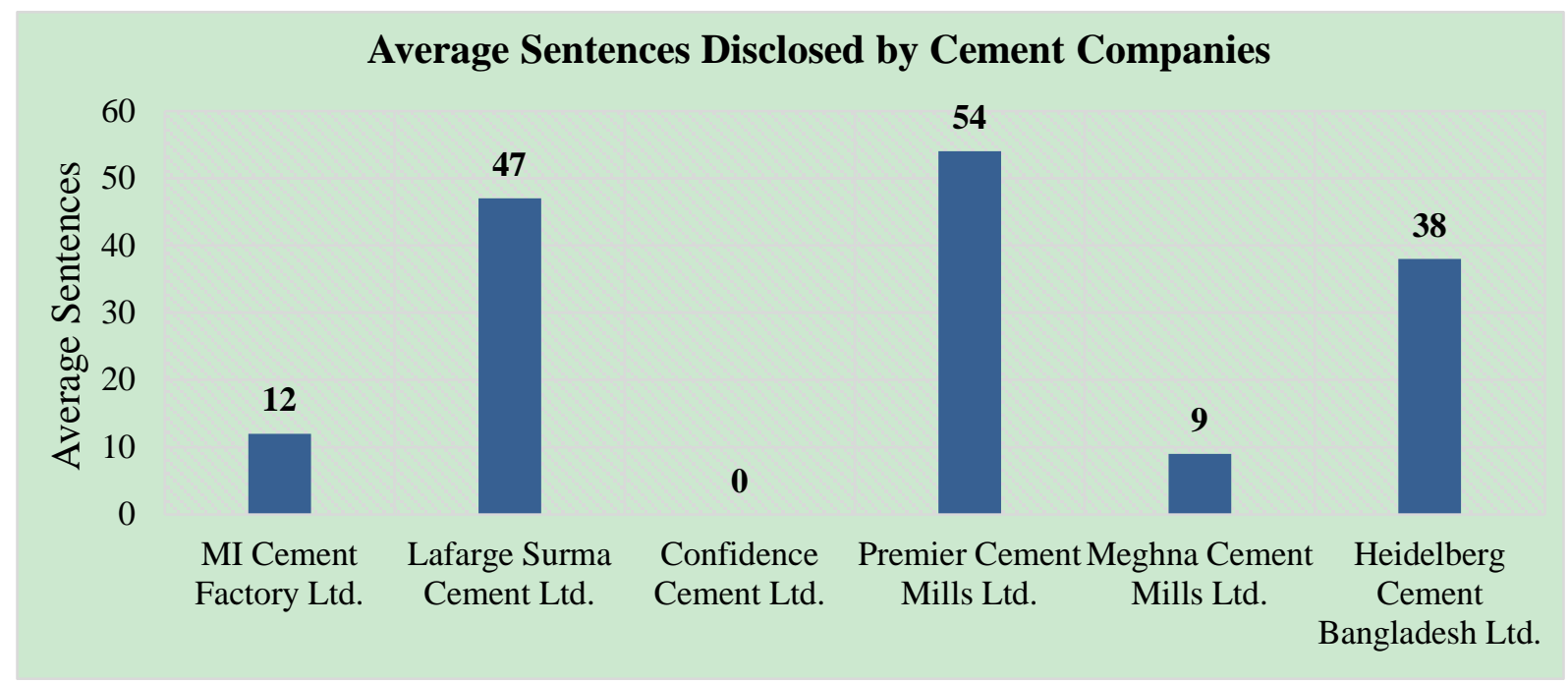

Figure 7. Average sentences disclosed by Cement Companies in the last five years (Annexure 4B)

The above figure presents the average sentence disclosure by the cement companies. It shows that Confidence Cement Ltd. disclosed nothing related to climate change and global warming issues. Average 12 sentences are disclosed by MI Cement Factory Ltd., 9 sentences by Meghna Cement Mills Ltd. in the last five years. Lafarge Surma Cement Ltd., Premier Cement Mills Ltd. and Heidelberg Cement Bangladesh Ltd. disclosed rigorously on different climate change $\&$ global warming issues such as on average 47 sentences, 54 sentences and 38 sentences respectively.

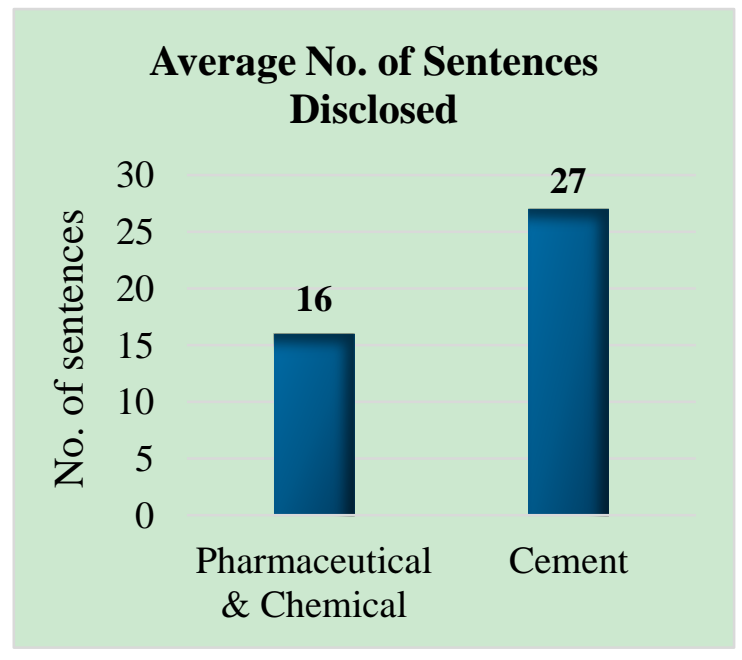

Figure 8. Sentences disclosure performance by pharmaceutical \& chemical and cement industry (Annexure 4) 


\section{MInstitute Mach $^{\text {In }}$}

International Journal of Accounting and Financial Reporting

ISSN 2162-3082

To present clearer picture of the prone to disclose on climate change and global warming, here is the figure showing the comparison between pharmaceutical $\&$ chemical and cement industry on the basis of average number of sentences disclosed in the last five years. By disclosing on average 27 sentences, cement companies disclosed average 11 more sentences than those of pharmaceutical \& chemical companies, representing $69 \%$ more sentences included in their annual reports on climate change and global warming.

\subsection{Disclosure Trend Comparison Between MNC and Bangladeshi Companies}

\subsubsection{Disclosure Overview of MNC and Bangladeshi Companies}
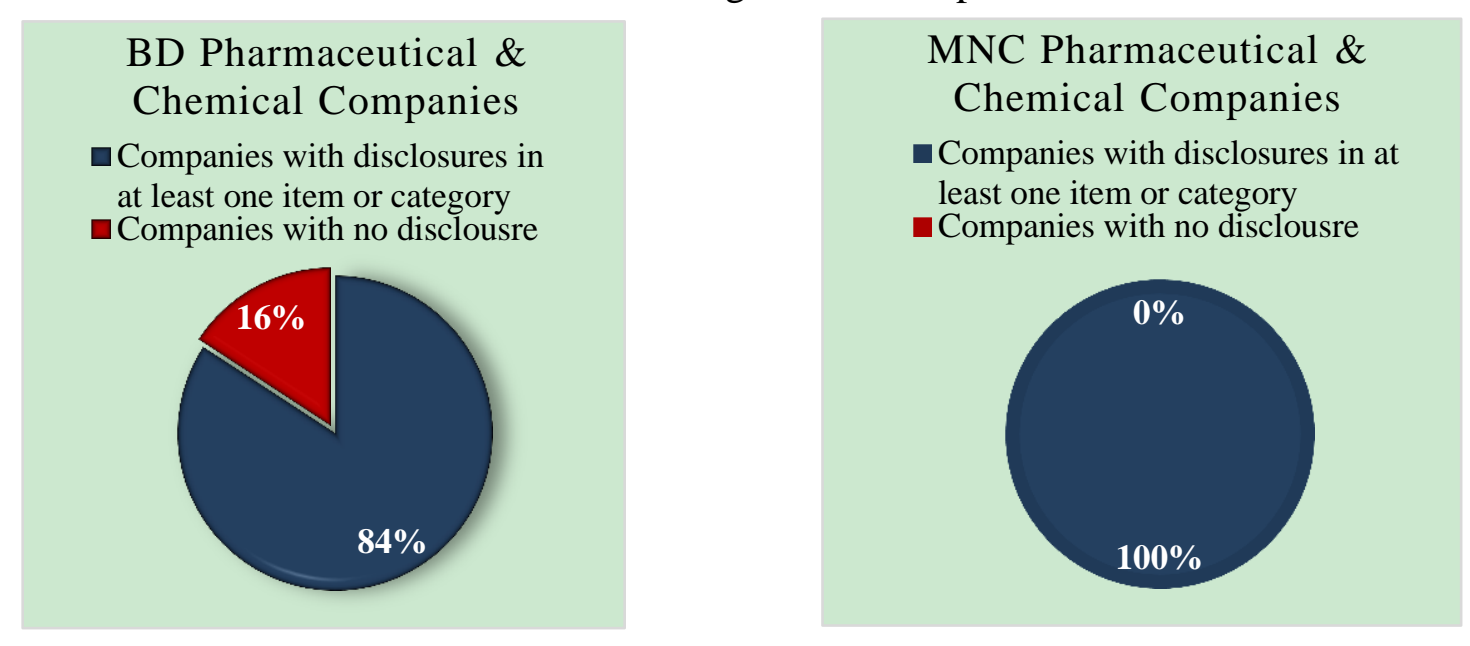

Figure 9. Comparative disclosure performance by Bangladeshi \& MNC Pharmaceutical \& Chemical Companies
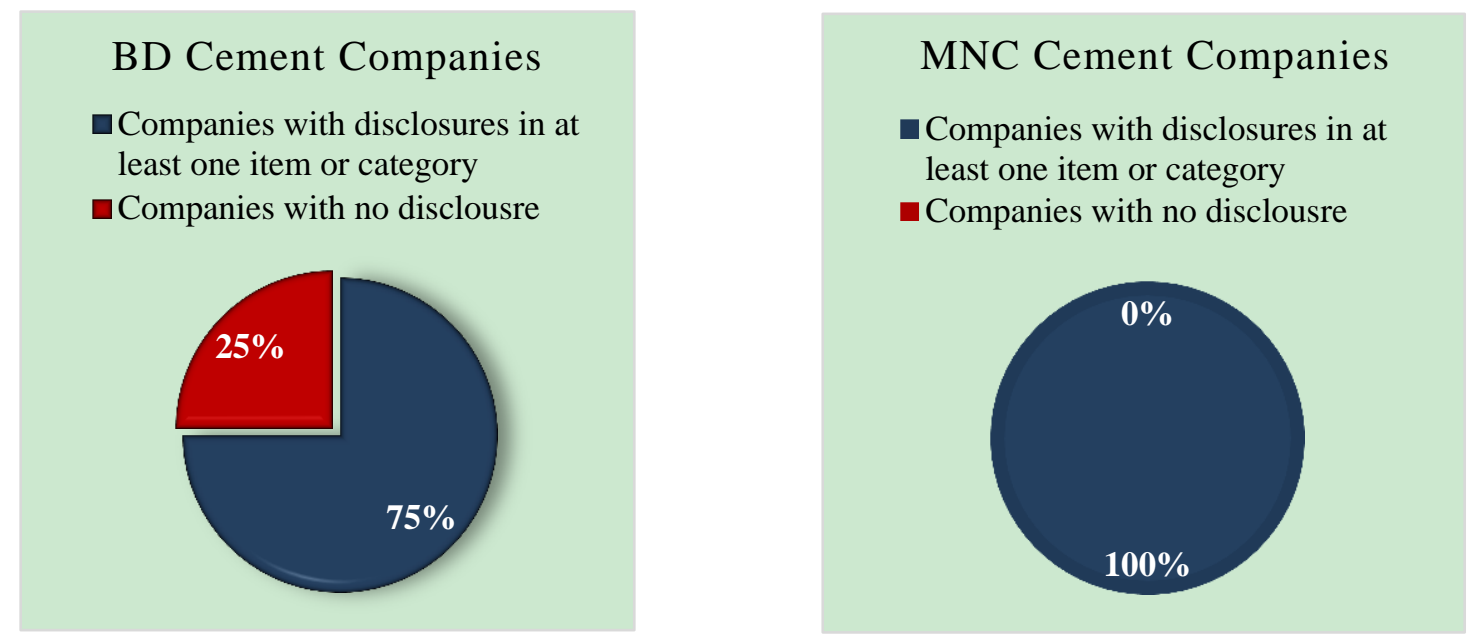

Figure 10. Comparative disclosure performance by Bangladeshi \& MNC cement companies

Multinational Companies of both pharmaceutical \& chemical and cement industry showed their importance on climate change and global warming issues as all of our sample MNCs disclosed at least one item or category related to it. On the other hand, Bangladeshi companies are less concern about this issue than the MNCs. Figure $9 \& 10$ exhumes that $84 \%$ 
of the sample Bangladeshi pharmaceutical \& chemical companies and $75 \%$ of the sample Bangladeshi cement companies disclosed about various issues on climate change and global warming. The remaining companies didn't do that.

5.5.2 MNC and Bangladeshi Companies' Yearly Average Disclosure Rate

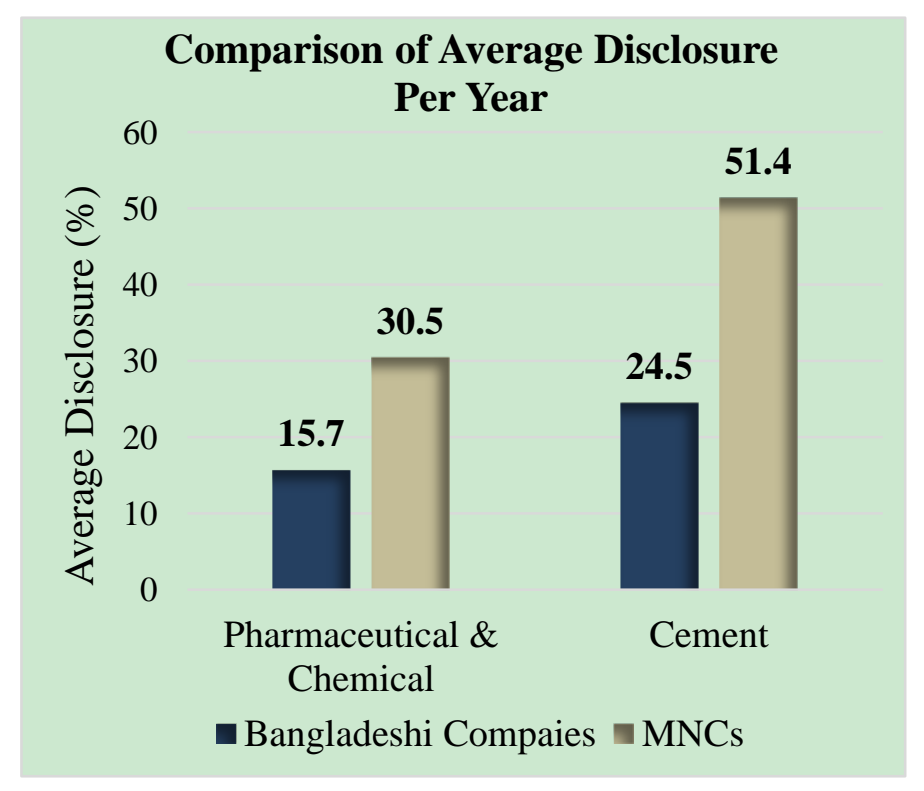

Figure 11. Comparison of average disclosure issues between MNCs \& Bangladeshi companies in both pharmaceutical \& chemical and cement industry

The above picture gives a close look on the issues disclosed by both multinational and Bangladeshi companies. The multinational pharmaceutical \& chemical companies disclosed average $30.5 \%$ of different climate change and global warming issues which is nearly two times higher than those of Bangladeshi companies who disclosed only average $15.7 \%$ issues (Annexure 5). At the same time the multinational cement companies disclosed average $51.4 \%$ of different climate change and global warming issues which is over two times higher than Bangladeshi companies who disclosed only average $24.5 \%$ issues (Annexure 6). Figure 11 brings to light that MNCs are highly prone to disclose more issues than that of Bangladeshi companies. Currently MNCs in our sample industries are disclosing more than $100 \%$ than that of our local companies that gives the sign of less proneness to disclose on such voluntary but socially most desired issues.

\section{Conclusions}

The objective of this study is to explore the narratives noted in the global warming of the listed companies of two emission intensive industries in Bangladesh. The study exhibits that $13 \%$ of sample companies disclosed nothing related to climate change and global warming issues though pharmaceutical \& chemical and cement companies are highly prone to climate change and global warming. Overall disclosure of the pharmaceutical \& chemical and cement sectors is close to moderate but some companies disclosed considerable information on climate change and global warming information in their annual reports. Companies' disclosure rate on different climate change and global warming issues is increasing year to 
year. Gradually the non-disclosing pharmaceutical \& chemical and cement companies are also engaging in climate change and global warming disclosure practice in their annual reports. Our results are consistent with the prediction of negative association arising from socio-political theory such as stakeholder theory and legitimacy theory. Both the theories predicted that in absence of stakeholders' monitoring and legitimacy in the society, companies are not willing to voluntarily disclose information. We improve the prior literature in way that we tried to relate voluntary disclosure theory particularly legitimacy theory in developing country perspective.

Nowadays climate related disclosure is limited not only to awareness but also in practice. Despite less contribution to the global climate change, the companies of Bangladesh are attempting to demonstrate their concerns for the legitimacy of their operations and their social contract with the society through climate change and global warming disclosure practices, even in the in-existence of any mandatory regulation. We recommended increasing monitoring by the government and other regulatory authorities of pharmaceutical \& chemical and cement companies in Bangladesh in addressing climate change and global warming issues in their annual report. Moreover, the present climate change and global warming disclosure practices of the Bangladeshi companies experience the deficiency of more detailed and in-depth practices. With the increasing awareness among the stakeholders regarding the adverse effects of the climate change and global warming, it is anticipated that there will be an increasing tendency to provide climate change and global warming disclosure practices. Comparative studies will be needed in future to gauge any uprising trend in the climate change and global warming reporting practices by the Bangladeshi companies.

Limitation of this study is it was exploratory in nature and took an all-inclusive approach. We do not use any industry-specific content analysis. Moreover, without going to detail disclosures we used the binary analysis, i.e., scoring 1 for the disclosures otherwise 0 . Future researchers can analyses the language of corporate disclosure on global warming issues.

\section{Acknowledgement}

The fund of this research is supported by University Grants Commission Research Fund, Bangladesh. The budget code is 5921.

\section{References}

ACCA. (2007). Disclosures on Climate Change: Australia. Association of Chartered Certified Accountants.

Ahmad, A. (2012). Environmental Accounting \& Reporting Practices, Significance and Issues: A Case from Bangladeshi Companies. Global Journal of Management and Business Research, 12(14).

Ahmad, N. N., \& Hossain, D. M. (2015). Climate Change and Global Warming Discourses and Disclosures in the Corporate Annual Reports: A Study on the Malaysian Companies. Global Conference on Business \& Social Science. Kuala Lumpur: Elsevier Ltd. https://doi.org/10.1016/j.sbspro.2015.01.361 
Amran, A., Ooi, S. K., Yeap, J. A. L., \& Jaafar, A. H. (2019). Governing climate change: the impact of board attributes on climate change disclosure. International Journal of $\begin{array}{lllll}\text { Environment } \quad \text { and } & \text { Sustainable }\end{array}$ http://doi.org/10.1504/IJESD.2019.10022566

Belal, A. R., Kabir, M. R., Cooper, S., Dey, P., Khan, N. A., Rahman, T., et al. (2010). Corporate Environmental and Climate Disclosures: Empirical Evidence from Bangladesh. Research in Accounting in Emerging Economies, 10, 145-167. https://doi.org/10.1108/S1479-3563(2010)0000010011

Department of Environment (DoE). (2007). Climate Change and Bangladesh. Climate Change Cell, Government of the People's Republic of Bangladesh, Dhaka.

Dey, P. K., Nakib, M., \& Dutta, P. (2017). Climate Change Disclosures in the Annual Reports: Evidence from Bangladesh. https://doi.org/10.5296/ajfa.v9i2.11736

Global Reporting Initiative and KPMG. (2007). Reporting the Business Implications of Climate Change in Sustainability Reports. A survey conducted by global reporting initiative and KPMGs global sustainability reporting service.

Hopwood, A. G. (2009). Accounting and the environment. Accounting, Organizations and Society, 34(3-4), 433-439. https://doi.org/10.1016/j.aos.2009.03.002

Intergovernmental Panel on Climate Change. (2007). Climate Change 2007: The Physical Science Basis. Cambridge: Cambridge University Press.

International Federation of Red Cross and Red Crescent Societies. (2014). Bangladesh: Flood. International Federation of Red Cross and Red Crescent Societies.

Khan, A., Muttakin, M. B., \& Siddiqui, J. (2013). Corporate Governance and Corporate Social Responsibility Disclosures: Evidence from and Emerging Economy. Journal of Business Ethics, 114, 207-223.

Kılıç, M., \& Kuzey, C. (2019). Determinants of climate change disclosures in the Turkish banking industry. International Journal of Bank Marketing, 37(3), 901-926. https://doi.org/10.1108/IJBM-08-2018-0206

Luo, L., Tang, Q., \& Lan, Y. (2013). Comparison of propensity of carbon disclosure between developing and developed countries: A resource constraint perspective. Accounting Research Journal, 26(1), 6-34.

Ministry of Environment and Forests (MoEF). (2009). Bangladesh Climate Change Strategy and Action Plan. Dhaka, Bangladesh: MoEF, Government of the People's Republic of Bangladesh.

Ministry of Planning. (2016). Bangladesh Disaster Related Statistics 2015. Dhaka: Bangladesh Bureau of Statistics.

Nurunnabi, M. (2015). Who cares about climate change reporting in developing countries? The market response to, and corporate accountability for, climate change in Bangladesh. 


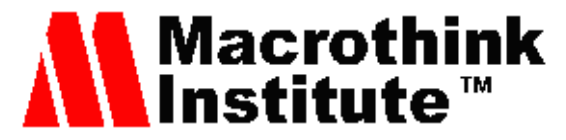

International Journal of Accounting and Financial Reporting ISSN 2162-3082

Environment,

Development

and

Sustainability,

18.

https://doi.org/10.1007/s10668-015-9632-3

Retrieved from https://www.worldometers.info/co2-emissions/bangladesh-co2-emissions/

Stechemesser, K., \& Guenther, E. (2012). Carbon accounting: a systematic literature review. Journal of Cleaner Production, 36, 17-38. https://doi.org/10.1016/j.jclepro.2012.02.021

The Daily Star. (2013, November). The Daily Star Archive. Retrieved December 2015, from http://archive.thedailystar.net/newDesign/cache/cached-news-details-157626.html

UNEP \& UNFCCC. (2002). Climate Change Information Kit. France: UNEP.

Wasim, R. (2019, June). Corporate (Non) Disclosure of Climate Change Information. Columbia Law Review, 119(5), 1311-1354. Retrieved from https://www.jstor.org/stable/26650740

Widdowson, H. G. (2007). Discourse Analysis. Oxford: Oxford University Press.

World Bank. (2014). Bangladesh: Community-Driven Attempts to Build Climate Change $\begin{array}{lllll}\text { Resiliency. } & \text { Retrieved } & 10 & \text { June } & \text { 2016, from }\end{array}$ http://www.worldbank.org/en/news/feature/2014/07/17/bangladesh-community-driven-attem pts-to-build-climate-change-resiliency

World Bank. (2015a). Salinity Intrusion in a Changing Climate Scenario will Hit Coastal Bangladesh Hard. $\quad$ Retrieved 12 June 2016, from http://www.worldbank.org/en/news/feature/2015/02/17/salinity-intrusion-in-changing-climate -scenario-will-hit-coastal-bangladesh-hard

World Bank. (2015b). Retrieved 12 June 2016, from http://www.worldbank.org/en/news/pressrelease/2015/07/01/new-world-bank-update-showsbangladesh-kenya-myanmar-and-tajikistan-as-middle-income-while-south-sudan-falls-back-t o-low-income 


\section{Annexure 1}

Companies annual report time frame

\begin{tabular}{|c|c|c|c|c|c|c|}
\hline \multirow[b]{2}{*}{ No. } & Company name & \multicolumn{5}{|c|}{ Annual report time frame (year) } \\
\hline & $\begin{array}{c}\text { Pharmaceutical \& Chemical } \\
\text { Industry }\end{array}$ & Year 1 & Year 2 & Year 3 & Year 4 & Year 5 \\
\hline 1 & $\begin{array}{l}\text { Advanced Chemical Industries (ACI) } \\
\text { Ltd. }\end{array}$ & 2014 & $2015-16$ & 2016-17 & 2017-18 & 2018-19 \\
\hline 2 & ACI Formulation Ltd. & 2014 & $2015-16$ & 2016-17 & 2017-18 & 2018-19 \\
\hline 3 & The ACME Laboratories Ltd. & 2014-15 & $2015-16$ & 2016-17 & 2017-18 & 2018-19 \\
\hline 4 & Berger Paints Bangladesh Ltd. & 2014 & 2015 & 2016-17 & $2017-18$ & 2018-19 \\
\hline 5 & BEXIMCO Synthetics Ltd. & 2014 & $2015-16$ & 2016-17 & 2017-18 & 2018-19 \\
\hline 6 & Marico Bangladesh Ltd. & 2014-15 & $2015-16$ & 2016-17 & 2017-18 & 2018-19 \\
\hline 7 & Reckitt Benckiser (Bd.) Ltd. & 2015 & 2016 & 2017 & 2018 & 2019 \\
\hline 8 & Renata Ltd. & 2014 & $2015-16$ & 2016-17 & $2017-18$ & 2018-19 \\
\hline 9 & FAR Chemical Industries Ltd. & 2014-15 & $2015-16$ & 2016-17 & $2017-18$ & 2018-19 \\
\hline 10 & AFC Agro Biotech Limited & 2014 & $2015-16$ & 2016-17 & 2017-18 & 2018-19 \\
\hline 11 & Active Fine Chemicals Limited & 2014 & $2015-16$ & 2016-17 & 2017-18 & 2018-19 \\
\hline 12 & BEACON Pharmaceuticals Ltd. & 2014-15 & $2015-16$ & 2016-17 & 2017-18 & 2018-19 \\
\hline 13 & BEXIMCO Pharmaceuticals Ltd. & 2014 & $2015-16$ & 2016-17 & $2017-18$ & 2018-19 \\
\hline 14 & Central Pharmaceuticals Ltd. & 2013-14 & $2015-16$ & 2016-17 & 2017-18 & 2018-19 \\
\hline 15 & GLOBAL Heavy Chemicals Ltd. & 2014 & $2015-16$ & 2016-17 & 2017-18 & 2018-19 \\
\hline 16 & $\begin{array}{l}\text { GlaxoSmithKline (GSK) Bangladesh } \\
\text { Ltd. }\end{array}$ & 2015 & 2016 & 2017 & 2018 & 2019 \\
\hline 17 & $\begin{array}{l}\text { The IBN SINA Pharmaceutical } \\
\text { Industry Ltd. }\end{array}$ & 2014 & 2015 & 2016-17 & 2017-18 & 2018-19 \\
\hline 18 & Imam Button Industries Ltd. & 2014-15 & $2015-16$ & 2016-17 & 2017-18 & 2018-19 \\
\hline 19 & Kohinoor Chemical Company Ltd. & $2014-15$ & $2015-16$ & 2016-17 & 2017-18 & 2018-19 \\
\hline 20 & Orion Infusion Ltd. & 2014-15 & $2015-16$ & 2016-17 & 2017-18 & 2018-19 \\
\hline 21 & Orion Pharma Ltd. & 2014 & $2015-16$ & 2016-17 & 2017-18 & 2018-19 \\
\hline 22 & Pharma Aids Ltd. & 2014-15 & 2015-16 & 2016-17 & $2017-18$ & 2018-19 \\
\hline 23 & Salvo Chemical Industries Ltd. & 2014 & $2015-16$ & 2016-17 & $2017-18$ & 2018-19 \\
\hline
\end{tabular}




\begin{tabular}{|r|l|l|l|l|l|l|}
\hline 24 & Square Pharmaceuticals Ltd. & $2014-15$ & $2015-16$ & $2016-17$ & $2017-18$ & $2018-19$ \\
\hline & \multicolumn{1}{|c|}{ Cement Industry } & & & & & \\
\hline 25 & MI Cement Factory Ltd. & $2014-15$ & $2015-16$ & $2016-17$ & $2017-18$ & $2018-19$ \\
\hline 26 & Lafarge Surma Cement Ltd. & 2014 & 2015 & 2016 & 2017 & 2018 \\
\hline 27 & Confidence Cement Ltd. & 2014 & $2015-16$ & $2016-17$ & $2017-18$ & $2018-19$ \\
\hline 28 & Premier Cement Mills Ltd. & $2014-15$ & $2015-16$ & $2016-17$ & $2017-18$ & $2018-19$ \\
\hline 29 & Meghna Cement Mills Ltd. & 2014 & $2015-16$ & $2016-17$ & $2017-18$ & $2018-19$ \\
\hline 30 & Heidelberg Cement Bangladesh Ltd. & 2014 & 2015 & 2016 & 2017 & 2018 \\
\hline
\end{tabular}

\section{Annexure 2}

A. Number of issues (out of 22) disclosed in the last five years by the companies

\begin{tabular}{|c|c|c|c|c|c|c|}
\hline \multirow[b]{2}{*}{ No. } & \multirow{2}{*}{$\begin{array}{c}\text { Company name } \\
\text { Pharmaceutical \& Chemical Industry }\end{array}$} & \multicolumn{5}{|c|}{ Disclosures in the last five years } \\
\hline & & Year-1 & Year-2 & Year-3 & Year-4 & Year-5 \\
\hline 1 & $\begin{array}{l}\text { Advanced Chemical Industries (ACI) } \\
\text { Ltd. }\end{array}$ & 8 & 7 & 7 & 7 & 7 \\
\hline 2 & ACI Formulation Ltd. & 6 & 6 & 5 & 5 & 4 \\
\hline 3 & The ACME Laboratories Ltd. & 11 & 12 & 12 & 12 & 11 \\
\hline 4 & Berger Paints Bangladesh Ltd. & 4 & 5 & 4 & 4 & 5 \\
\hline 5 & BEXIMCO Synthetics Ltd. & 0 & 0 & 0 & 0 & 0 \\
\hline 6 & Marico Bangladesh Ltd. & 5 & 8 & 8 & 7 & 8 \\
\hline 7 & Reckitt Benckiser (Bd.) Ltd. & 9 & 12 & 11 & 11 & 11 \\
\hline 8 & Renata Ltd. & 0 & 0 & 0 & 0 & 2 \\
\hline 9 & FAR Chemical Industries Ltd & 2 & 2 & 2 & 2 & 2 \\
\hline 10 & AFC Agro Biotech Ltd. & 4 & 4 & 4 & 4 & 3 \\
\hline 11 & Active Fine Chemicals Ltd. & 0 & 3 & 3 & 3 & 3 \\
\hline 12 & BEACON Pharmaceuticals Ltd. & 0 & 0 & 0 & 0 & 1 \\
\hline 13 & BEXIMCO Pharmaceuticals Ltd & 4 & 4 & 4 & 9 & 13 \\
\hline 14 & Central Pharmaceuticals Ltd. & 3 & 3 & 3 & 3 & 3 \\
\hline
\end{tabular}




\begin{tabular}{|c|c|c|c|c|c|c|}
\hline 15 & GLOBAL Heavy Chemicals Ltd & 0 & 1 & 1 & 1 & 1 \\
\hline 16 & $\begin{array}{l}\text { GlaxoSmithKline (GSK) Bangladesh } \\
\text { Ltd. }\end{array}$ & 3 & 6 & 5 & 2 & 4 \\
\hline 17 & $\begin{array}{l}\text { The IBN SINA Pharmaceutical Industry } \\
\text { Ltd. }\end{array}$ & 4 & 3 & 3 & 9 & 7 \\
\hline 18 & Imam Button Industries Ltd. & 0 & 0 & 0 & 0 & 0 \\
\hline 19 & Kohinoor Chemical Company Ltd. & 3 & 3 & 7 & 3 & 3 \\
\hline 20 & Orion Infusion Ltd. & 6 & 7 & 7 & 5 & 6 \\
\hline 21 & Orion Pharma Ltd. & 3 & 9 & 13 & 13 & 14 \\
\hline 22 & Pharma Aids Ltd. & 0 & 0 & 0 & 0 & 0 \\
\hline 23 & Salvo Chemical Industries Ltd. & 1 & 1 & 1 & 1 & 1 \\
\hline 24 & Square Pharmaceuticals Ltd. & 3 & 3 & 3 & 3 & 3 \\
\hline & Cement Industry & & & & & \\
\hline 25 & MI Cement Factory Ltd. & 2 & 5 & 5 & 4 & 4 \\
\hline 26 & Lafarge Surma Cement Ltd. & 9 & 9 & 10 & 9 & 13 \\
\hline 27 & Confidence Cement Ltd. & 0 & 0 & 0 & 0 & 0 \\
\hline 28 & Premier Cement Mills Ltd. & 9 & 13 & 15 & 16 & 16 \\
\hline 29 & Meghna Cement Mills Ltd. & 1 & 2 & 2 & 6 & 8 \\
\hline 30 & Heidelberg Cement Bangladesh Ltd. & 8 & 15 & 14 & 14 & 12 \\
\hline
\end{tabular}

B. Percentage of issues (out of 22) disclosed in the last five years by the companies

\begin{tabular}{|c|l|c|c|c|c|c|c|}
\hline \multirow{2}{*}{ No. } & \multicolumn{2}{|c|}{$\begin{array}{c}\text { Dompany name } \\
\text { (\%) }\end{array}$} & \multicolumn{3}{c|}{} \\
\cline { 2 - 8 } & \multicolumn{1}{|c|}{$\begin{array}{c}\text { Pharmaceutical \& Chemical } \\
\text { Industry }\end{array}$} & Year-1 & Year-2 & Year-3 & Year-4 & Year-5 & Avg. \\
\hline 1 & $\begin{array}{l}\text { Advanced Chemical Industries (ACI) } \\
\text { Ltd. }\end{array}$ & 36.4 & 31.8 & 31.8 & 31.8 & 31.8 & $\mathbf{3 2 . 7}$ \\
\hline 2 & ACI Formulation Ltd. & 27.3 & 27.3 & 22.7 & 22.7 & 18.2 & $\mathbf{2 3 . 6}$ \\
\hline 3 & The ACME Laboratories Ltd. & 50 & 54.5 & 54.5 & 54.5 & 50 & $\mathbf{5 2 . 7}$ \\
\hline 4 & Berger Paints Bangladesh Ltd. & 18.2 & 22.7 & 18.2 & 18.2 & 22.7 & $\mathbf{2 0}$ \\
\hline 5 & BEXIMCO Synthetics Ltd. & 0 & 0 & 0 & 0 & 0 & $\mathbf{0}$ \\
\hline
\end{tabular}


International Journal of Accounting and Financial Reporting ISSN 2162-3082

2020, Vol. 10, No. 4

\begin{tabular}{|c|c|c|c|c|c|c|c|}
\hline 6 & Marico Bangladesh Ltd. & 22.7 & 36.4 & 36.4 & 31.8 & 36.4 & 32.7 \\
\hline 7 & Reckitt Benckiser (Bd.) Ltd. & 41 & 54.5 & 50 & 50 & 50 & 49 \\
\hline 8 & Renata Ltd. & 0 & 0 & 0 & 0 & 9 & 1.8 \\
\hline 9 & FAR Chemical Industries Ltd & 9 & 9 & 9 & 9 & 9 & 9 \\
\hline 10 & AFC Agro Biotech Ltd. & 18.2 & 18.2 & 18.2 & 18.2 & 13.6 & 17.3 \\
\hline 11 & Active Fine Chemicals Ltd. & 0 & 13.6 & 13.6 & 13.6 & 13.6 & 10.9 \\
\hline 12 & BEACON Pharmaceuticals Ltd. & 0 & 0 & 0 & 0 & 4.5 & 0.9 \\
\hline 13 & BEXIMCO Pharmaceuticals Ltd & 18.2 & 18.2 & 18.2 & 41 & 59.1 & 30.9 \\
\hline 14 & Central Pharmaceuticals Ltd. & 13.6 & 13.6 & 13.6 & 13.6 & 13.6 & 13.6 \\
\hline 15 & GLOBAL Heavy Chemicals Ltd & 0 & 4.5 & 4.5 & 4.5 & 4.5 & 3.6 \\
\hline 16 & $\begin{array}{l}\text { GlaxoSmithKline (GSK) Bangladesh } \\
\text { Ltd. }\end{array}$ & 13.6 & 27.3 & 22.7 & 9 & 18.2 & 18.2 \\
\hline 17 & $\begin{array}{l}\text { The IBN SINA Pharmaceutical } \\
\text { Industry Ltd. }\end{array}$ & 18.2 & 13.6 & 13.6 & 41 & 31.8 & 23.6 \\
\hline 18 & Imam Button Industries Ltd. & 0 & 0 & 0 & 0 & 0 & $\mathbf{0}$ \\
\hline 19 & Kohinoor Chemical Company Ltd. & 13.6 & 13.6 & 31.8 & 13.6 & 13.6 & 17.2 \\
\hline 20 & Orion Infusion Ltd. & 27.3 & 31.8 & 31.8 & 22.7 & 27.3 & 28.2 \\
\hline 21 & Orion Pharma Ltd. & 13.6 & 41 & 59.1 & 59.1 & 63.6 & 47.3 \\
\hline 22 & Pharma Aids Ltd. & 0 & 0 & 0 & 0 & 0 & $\mathbf{0}$ \\
\hline 23 & Salvo Chemical Industries Ltd. & 4.5 & 4.5 & 4.5 & 4.5 & 4.5 & 4.5 \\
\hline \multirow[t]{3}{*}{24} & Square Pharmaceuticals Ltd. & 13.6 & 13.6 & 13.6 & 13.6 & 13.6 & 13.6 \\
\hline & Average & 15 & 18.7 & 19.5 & 19.7 & 21.2 & \\
\hline & Cement Industry & & & & & & \\
\hline 25 & MI Cement Factory Ltd. & 9 & 22.7 & 22.7 & 18.2 & 18.2 & 18.2 \\
\hline 26 & Lafarge Surma Cement Ltd. & 41 & 41 & 45.5 & 41 & 59.1 & 45.5 \\
\hline 27 & Confidence Cement Ltd. & 0 & 0 & 0 & 0 & 0 & $\mathbf{0}$ \\
\hline 28 & Premier Cement Mills Ltd. & 41 & 59.1 & 68.2 & 72.7 & 72.7 & 62.7 \\
\hline 29 & Meghna Cement Mills Ltd. & 4.5 & 9 & 9 & 27.3 & 36.4 & 17.2 \\
\hline \multirow[t]{3}{*}{30} & Heidelberg Cement Bangladesh Ltd. & 36.4 & 68.2 & 63.6 & 63.6 & 54.5 & 57.3 \\
\hline & Average & 22 & 33.3 & 34.8 & 37.1 & 40.2 & \\
\hline & Average of Total Sample & 16.4 & 21.7 & 22.6 & 23.2 & 25 & \\
\hline
\end{tabular}




\section{Annexure 3}

A. Number of sample companies disclosing the issues in the last five years $(n=30)$

\begin{tabular}{|l|c|c|c|c|c|}
\hline \multicolumn{1}{|c|}{ Disclosure Issues } & \multicolumn{3}{|c|}{ No. of companies disclosing the issues } \\
\cline { 2 - 6 } & $\begin{array}{c}\text { Year } \\
\mathbf{0 1}\end{array}$ & $\begin{array}{c}\text { Year } \\
\mathbf{0 2}\end{array}$ & $\begin{array}{c}\text { Year } \\
\mathbf{0 3}\end{array}$ & $\begin{array}{c}\text { Year } \\
\mathbf{0 4}\end{array}$ & $\begin{array}{c}\text { Year } \\
\mathbf{0 5}\end{array}$ \\
\hline $\begin{array}{l}\text { Organization has a separate Environment, health and safety } \\
\text { plan and it discloses in the publicly available documents. }\end{array}$ & 9 & 10 & 11 & 13 & 13 \\
\hline $\begin{array}{l}\text { Anything mentioned about the climate change or global } \\
\text { warming in the chairman's statement/CEO/ Directors report } \\
\text { in the annual report. }\end{array}$ & 2 & 3 & 3 & 3 & 8 \\
\hline $\begin{array}{l}\text { Anything mentioned about the environment in the } \\
\text { chairman's statement/CEO/Directors report in the annual } \\
\text { report. }\end{array}$ & 18 & 20 & 20 & 17 & 19 \\
\hline Policy to develop alternative/ renewable energy & 4 & 7 & 8 & 7 & 6 \\
\hline Energy consumption in the operation & 3 & 7 & 8 & 7 & 8 \\
\hline Energy saving and efficiency & 7 & 8 & 8 & 9 & 10 \\
\hline Management approach for raw materials & 11 & 14 & 15 & 14 & 13 \\
\hline $\begin{array}{l}\text { Management approach for } \\
\text { i. Effluents management } \\
\text { ii. Waste management }\end{array}$ & 6 & 9 & 10 & 12 & 7 \\
\hline Mention anything about the biodiversity & 6 & 8 & 9 & 12 & 11 \\
\hline Preserving biodiversity & 2 & 2 & 5 & 3 & 6 \\
\hline Air pollution & 3 & 3 & 4 & 4 & 5 \\
\hline $\begin{array}{l}\text { Management approach for emissions: } \\
\text { i. GHG/CO } \\
\text { ii. ODS } \\
\text { iii. Numerical data on gas emission }\end{array}$ & 2 & 5 & 6 & 6 & 7 \\
\hline $\begin{array}{l}\text { Policy to comply with GRI guidelines, GHG Protocol } \\
\text { standard or any other voluntary standards. }\end{array}$ & 10 & 12 & 9 & 9 & 12 \\
\hline Tree plantation & 4 & 4 & 6 & 5 & 5 \\
\hline $\begin{array}{l}\text { Significant impact of activities, products \& services on } \\
\text { Climate change \& global warming }\end{array}$ & 2 & 5 & 5 & 5 & 4 \\
\hline $\begin{array}{l}\text { Is there any separate section is devoted to climate change } \\
\text { and/or global warming? }\end{array}$ & 0 & 0 & 0 & 0 & 0 \\
\hline $\begin{array}{l}\text { Do they have any specific board committee related to } \\
\text { environment and/or climate change? }\end{array}$ & 2 & 3 & 2 & 3 & 5 \\
\hline Compliance with environmental laws and regulations & 13 & 14 & 12 & 13 & 16 \\
\hline Kyoto protocol and/or Paris Agreement & 0 & 0 & 0 & 1 & 0 \\
\hline
\end{tabular}


B. Percentage of the total sample $(n=30)$

\begin{tabular}{|c|c|c|c|c|c|}
\hline \multirow[b]{2}{*}{ Disclosure Issues } & \multicolumn{5}{|c|}{ Percentage of the total sample $(n=30)$} \\
\hline & Year 01 & Year 02 & Year 03 & Year 04 & Year 05 \\
\hline $\begin{array}{l}\text { Organization has a separate Environment, health and } \\
\text { safety plan and it discloses in the publicly available } \\
\text { documents. }\end{array}$ & 30 & 33.3 & 36.7 & 43.3 & 43.3 \\
\hline $\begin{array}{l}\text { Anything mentioned about the climate change or global } \\
\text { warming in the chairman's statement/ CEO/ Directors } \\
\text { report in the annual report. }\end{array}$ & 6.7 & 10 & 10 & 10 & 26.7 \\
\hline $\begin{array}{l}\text { Anything mentioned about the environment in the } \\
\text { chairman's statement/CEO/Directors report in the annual } \\
\text { report. }\end{array}$ & 60 & 66.7 & 66.7 & 56.7 & 63.3 \\
\hline Policy to develop alternative/ renewable energy & 13.3 & 23.3 & 26.7 & 23.3 & 20 \\
\hline Energy consumption in the operation & 10 & 23.3 & 26.7 & 23.3 & 26.7 \\
\hline Energy saving and efficiency & 23.3 & 26.7 & 26.7 & 30 & 33.3 \\
\hline Management approach for raw materials & 36.7 & 46.7 & 50 & 46.7 & 43.3 \\
\hline Management approach for & & & & & \\
\hline i. Effluents management & 20 & 30 & 33.3 & 46.7 & 23.3 \\
\hline ii. Waste management & 20 & 26.7 & 30 & 46.7 & 46.7 \\
\hline Mention anything about the biodiversity. & 6.7 & 6.7 & 16.7 & 10 & 20 \\
\hline Preserving biodiversity & 10 & 10 & 13.3 & 13.3 & 16.7 \\
\hline Air pollution & 6.7 & 16.7 & 20 & 20 & 23.3 \\
\hline Management approach for emissions: & & & & & \\
\hline i. $\quad \mathrm{GHG} / \mathrm{CO}_{2}$ & 10 & 20 & 20 & 20 & 20 \\
\hline ii. ODS & 3.3 & 3.3 & 3.3 & 6.7 & 6.7 \\
\hline iii. Numerical data on gas emission & 3.3 & 6.7 & 3.3 & 3.3 & 3.3 \\
\hline $\begin{array}{l}\text { Policy to comply with GRI guidelines, GHG Protocol } \\
\text { standard or any other voluntary standards. }\end{array}$ & 33.3 & 40 & 30 & 30 & 40 \\
\hline Tree plantation & 13.3 & 13.3 & 20 & 16.7 & 16.7 \\
\hline $\begin{array}{l}\text { Significant impact of activities, products \& services on } \\
\text { Climate change \& global warming }\end{array}$ & 6.7 & 16.7 & 16.7 & 16.7 & 13.3 \\
\hline $\begin{array}{l}\text { Is there any separate section is devoted to climate change } \\
\text { and/or global warming? }\end{array}$ & 0 & 0 & 0 & 0 & 0 \\
\hline $\begin{array}{l}\text { Do they have any specific board committee related to } \\
\text { environment and/or climate change? }\end{array}$ & 6.7 & 10 & 6.7 & 10 & 16.7 \\
\hline Compliance with environmental laws and regulations & 43.3 & 46.7 & 40 & 43.3 & 53.3 \\
\hline Kyoto protocol and/or Paris Agreement & 0 & 0 & 0 & 3.3 & 0 \\
\hline Average & $16.5 \%$ & $21.7 \%$ & $22.6 \%$ & $23.6 \%$ & $25.3 \%$ \\
\hline
\end{tabular}


C. Number of Pharmaceutical \& Chemical companies disclosing the issues in the last five years $(n=24)$

\begin{tabular}{|c|c|c|c|c|c|}
\hline \multirow[b]{2}{*}{ Disclosure Issues } & \multicolumn{5}{|c|}{ No. of companies disclosing the issues } \\
\hline & $\begin{array}{c}\text { Year } \\
01\end{array}$ & $\begin{array}{c}\text { Year } \\
02\end{array}$ & $\begin{array}{c}\text { Year } \\
03\end{array}$ & Year 04 & $\begin{array}{c}\text { Year } \\
05\end{array}$ \\
\hline $\begin{array}{l}\text { Organization has a separate Environment, health and safety } \\
\text { plan and it discloses in the publicly available documents. }\end{array}$ & 6 & 7 & 8 & 10 & 9 \\
\hline $\begin{array}{l}\text { Anything mentioned about the climate change or global } \\
\text { warming in the chairman's statement/CEO/ Directors report } \\
\text { in the annual report. }\end{array}$ & 1 & 1 & 1 & 1 & 4 \\
\hline $\begin{array}{l}\text { Anything mentioned about the environment in the } \\
\text { chairman's statement/CEO/Directors report in the annual } \\
\text { report. }\end{array}$ & 14 & 16 & 16 & 12 & 14 \\
\hline Policy to develop alternative/ renewable energy & 3 & 4 & 5 & 4 & 3 \\
\hline Energy consumption in the operation & 2 & 4 & 5 & 4 & 5 \\
\hline Energy saving and efficiency & 5 & 5 & 5 & 7 & 7 \\
\hline Management approach for raw materials & 8 & 10 & 11 & 10 & 10 \\
\hline Management approach for & & & & & \\
\hline i. Effluents management & 6 & 9 & 8 & 9 & 6 \\
\hline ii. Waste management & 5 & 7 & 7 & 9 & 8 \\
\hline Mention anything about the biodiversity & 1 & 1 & 2 & 1 & 3 \\
\hline Preserving biodiversity & 1 & 1 & 1 & 1 & 2 \\
\hline Air pollution & 1 & 2 & 4 & 4 & 5 \\
\hline Management approach for emissions: & & & & & \\
\hline i. $\quad \mathrm{GHG} / \mathrm{CO}_{2}$ & 2 & 4 & 4 & 3 & 3 \\
\hline ii. ODS & 1 & 1 & 1 & 2 & 2 \\
\hline iii. Numerical data on gas emission & 1 & 1 & 1 & 1 & 1 \\
\hline $\begin{array}{l}\text { Policy to comply with GRI guidelines, GHG Protocol } \\
\text { standard or any other voluntary standards. }\end{array}$ & 8 & 9 & 7 & 7 & 8 \\
\hline Tree plantation & 2 & 2 & 5 & 4 & 3 \\
\hline $\begin{array}{l}\text { Significant impact of activities, products \& services on } \\
\text { Climate change \& global warming }\end{array}$ & 2 & 2 & 2 & 3 & 2 \\
\hline $\begin{array}{l}\text { Is there any separate section is devoted to climate change } \\
\text { and/or global warming? }\end{array}$ & 0 & 0 & 0 & 0 & 0 \\
\hline $\begin{array}{l}\text { Do they have any specific board committee related to } \\
\text { environment and/or climate change? }\end{array}$ & 1 & 2 & 1 & 1 & 3 \\
\hline Compliance with environmental laws and regulations & 10 & 11 & 9 & 10 & 13 \\
\hline Kyoto protocol and/or Paris Agreement & 0 & 0 & 0 & 1 & 0 \\
\hline
\end{tabular}


D. Percentage of the total sample $(n=24)$ of Pharmaceutical \& Chemical companies

\begin{tabular}{|c|c|c|c|c|c|}
\hline \multirow{2}{*}{ Disclosure Issues } & \multicolumn{5}{|c|}{ Percentage of the total sample $(n=24)$} \\
\hline & Year 01 & Year 02 & Year 03 & Year 04 & Year 05 \\
\hline $\begin{array}{l}\text { Organization has a separate Environment, health and safety } \\
\text { plan and it discloses in the publicly available documents. }\end{array}$ & 25 & 29.2 & 33.3 & 41.7 & 37.5 \\
\hline $\begin{array}{l}\text { Anything mentioned about the climate change or global } \\
\text { warming in the chairman's statement/ CEO/Directors report } \\
\text { in the annual report. }\end{array}$ & 4.2 & 4.2 & 4.2 & 4.2 & 16.7 \\
\hline $\begin{array}{l}\text { Anything mentioned about the environment in the } \\
\text { chairman's statement/CEO/Directors report in the annual } \\
\text { report. }\end{array}$ & 58.3 & 66.7 & 66.7 & 50 & 58.3 \\
\hline Policy to develop alternative/ renewable energy & 12.5 & 16.7 & 20.8 & 16.7 & 12.5 \\
\hline Energy consumption in the operation & 8.3 & 16.7 & 20.8 & 16.7 & 20.8 \\
\hline Energy saving and efficiency & 20.8 & 20.8 & 20.8 & 29.2 & 29.2 \\
\hline Management approach for raw materials & 33.3 & 41.7 & 45.8 & 41.7 & 41.7 \\
\hline Management approach for & & & & & \\
\hline i. Effluents management & 25 & 37.5 & 33.3 & 37.5 & 25 \\
\hline ii. Waste management & 20.8 & 29.2 & 29.2 & 37.5 & 33.3 \\
\hline Mention anything about the biodiversity. & 4.2 & 4.2 & 8.3 & 4.2 & 12.5 \\
\hline Preserving biodiversity & 4.2 & 4.2 & 4.2 & 4.2 & 8.3 \\
\hline Air pollution & 4.2 & 8.3 & 16.7 & 16.7 & 20.8 \\
\hline Management approach for emissions: & & & & & \\
\hline i. $\quad \mathrm{GHG} / \mathrm{CO}_{2}$ & 8.3 & 16.7 & 16.7 & 12.5 & 12.5 \\
\hline ii. ODS & 4.2 & 4.2 & 4.2 & 8.3 & 8.3 \\
\hline iii. Numerical data on gas emission & 4.2 & 4.2 & 4.2 & 4.2 & 4.2 \\
\hline $\begin{array}{l}\text { Policy to comply with GRI guidelines, GHG Protocol } \\
\text { standard or any other voluntary standards. }\end{array}$ & 33.3 & 37.5 & 29.2 & 29.2 & 33.3 \\
\hline Tree plantation & 8.3 & 8.3 & 20.8 & 16.7 & 12.5 \\
\hline $\begin{array}{l}\text { Significant impact of activities, products \& services on } \\
\text { Climate change \& global warming }\end{array}$ & 8.3 & 8.3 & 8.3 & 12.5 & 8.3 \\
\hline $\begin{array}{l}\text { Is there any separate section is devoted to climate change } \\
\text { and/or global warming? }\end{array}$ & 0 & 0 & 0 & 0 & 0 \\
\hline $\begin{array}{l}\text { Do they have any specific board committee related to } \\
\text { environment and/or climate change? }\end{array}$ & 4.2 & 8.3 & 4.2 & 4.2 & 12.5 \\
\hline Compliance with environmental laws and regulations & 41.7 & 45.8 & 37.5 & 41.7 & 54.2 \\
\hline Kyoto protocol and/or Paris Agreement & 0 & 0 & 0 & 4.2 & 0 \\
\hline Average & $15.15 \%$ & $18.76 \%$ & $19.5 \%$ & $19.72 \%$ & $21 \%$ \\
\hline
\end{tabular}


E. Number of cement companies $(n=6)$ disclosing the issues

\begin{tabular}{|c|c|c|c|c|c|}
\hline \multirow[b]{2}{*}{ Disclosure Issues } & \multicolumn{5}{|c|}{ No. of companies disclosing the issues } \\
\hline & $\begin{array}{c}\text { Year } \\
01\end{array}$ & $\begin{array}{c}\text { Year } \\
02\end{array}$ & $\begin{array}{c}\text { Year } \\
03\end{array}$ & $\begin{array}{c}\text { Year } \\
04\end{array}$ & $\begin{array}{c}\text { Year } \\
05\end{array}$ \\
\hline $\begin{array}{l}\text { Organization has a separate Environment, health and safety } \\
\text { plan and it discloses in the publicly available documents. }\end{array}$ & 3 & 3 & 3 & 3 & 4 \\
\hline $\begin{array}{l}\text { Anything mentioned about the climate change or global } \\
\text { warming in the chairman's statement/CEO/ Directors report in } \\
\text { the annual report. }\end{array}$ & 1 & 2 & 2 & 2 & 4 \\
\hline $\begin{array}{l}\text { Anything mentioned about the environment in the chairman's } \\
\text { statement/CEO/Directors report in the annual report. }\end{array}$ & 4 & 4 & 4 & 5 & 5 \\
\hline Policy to develop alternative/ renewable energy & 1 & 3 & 3 & 3 & 3 \\
\hline Energy consumption in the operation & 1 & 3 & 3 & 3 & 3 \\
\hline Energy saving and efficiency & 2 & 3 & 3 & 2 & 3 \\
\hline Management approach for raw materials & 3 & 4 & 4 & 4 & 3 \\
\hline $\begin{array}{ll}\text { Management approach for } \\
\text { i. } & \text { Effluents management } \\
\text { ii. } & \text { Waste management } \\
\end{array}$ & $\begin{array}{l}0 \\
1\end{array}$ & $\begin{array}{l}0 \\
1\end{array}$ & $\begin{array}{l}2 \\
2\end{array}$ & $\begin{array}{l}3 \\
3\end{array}$ & $\begin{array}{l}1 \\
3\end{array}$ \\
\hline Mention anything about the biodiversity & 1 & 1 & 3 & 2 & 3 \\
\hline Preserving biodiversity & 2 & 2 & 3 & 3 & 3 \\
\hline Air pollution & 1 & 3 & 2 & 2 & 2 \\
\hline \begin{aligned} \multicolumn{2}{l}{ Management approach for emissions: } \\
$\begin{aligned} \text { i. } & \mathrm{GHG} / \mathrm{CO}_{2} \\
\text { ii. } & \mathrm{ODS} \\
\text { iii. } & \text { Numerical data on gas emission }\end{aligned}\end{aligned}$ & $\begin{array}{l}1 \\
0 \\
0\end{array}$ & $\begin{array}{l}2 \\
0 \\
1\end{array}$ & $\begin{array}{l}2 \\
0 \\
0\end{array}$ & $\begin{array}{l}3 \\
0 \\
0\end{array}$ & $\begin{array}{l}3 \\
0 \\
0\end{array}$ \\
\hline $\begin{array}{l}\text { Policy to comply with GRI guidelines, GHG Protocol standard } \\
\text { or any other voluntary standards. }\end{array}$ & 2 & 3 & 2 & 2 & 4 \\
\hline Tree plantation & 2 & 2 & 1 & 1 & 2 \\
\hline $\begin{array}{l}\text { Significant impact of activities, products \& services on } \\
\text { Climate change \& global warming }\end{array}$ & 0 & 3 & 3 & 3 & 2 \\
\hline $\begin{array}{l}\text { Is there any separate section is devoted to climate change } \\
\text { and/or global warming? }\end{array}$ & 0 & 0 & 0 & 0 & 0 \\
\hline $\begin{array}{l}\text { Do they have any specific board committee related to } \\
\text { environment and/or climate change? }\end{array}$ & 1 & 1 & 1 & 2 & 2 \\
\hline Compliance with environmental laws and regulations & 3 & 3 & 3 & 3 & 3 \\
\hline Kyoto protocol and/or Paris Agreement. & 0 & 0 & 0 & 0 & 0 \\
\hline
\end{tabular}


F. Percentage of the total sample $(n=6)$ of Cement companies

\begin{tabular}{|c|c|c|c|c|c|}
\hline \multirow[b]{2}{*}{ Disclosure Issues } & \multicolumn{5}{|c|}{ Percentage of the total sample $(n=6)$} \\
\hline & Year 01 & Year 02 & Year 03 & Year 04 & Year 05 \\
\hline $\begin{array}{l}\text { Organization has a separate Environment, health and } \\
\text { safety plan and it discloses in the publicly available } \\
\text { documents. }\end{array}$ & 50 & 50 & 50 & 50 & 66.7 \\
\hline $\begin{array}{l}\text { Anything mentioned about the climate change or global } \\
\text { warming in the chairman's statement/ CEO/Directors } \\
\text { report in the annual report. }\end{array}$ & 16.7 & 33.3 & 33.3 & 33.3 & 66.7 \\
\hline $\begin{array}{l}\text { Anything mentioned about the environment in the } \\
\text { chairman's statement/CEO/Directors report in the annual } \\
\text { report. }\end{array}$ & 66.7 & 66.7 & 66.7 & 83.3 & 83.3 \\
\hline Policy to develop alternative/ renewable energy & 16.7 & 50 & 50 & 50 & 50 \\
\hline Energy consumption in the operation & 16.7 & 50 & 50 & 50 & 50 \\
\hline Energy saving and efficiency & 33.3 & 50 & 50 & 33.3 & 50 \\
\hline Management approach for raw materials & 50 & 66.7 & 66.7 & 66.7 & 50 \\
\hline Management approach for & & & & & \\
\hline i. Effluents management & 0 & 0 & 33.3 & 50 & 16.7 \\
\hline ii. Waste management & 16.7 & 16.7 & 33.3 & 50 & 50 \\
\hline Mention anything about the biodiversity. & 16.7 & 16.7 & 50 & 33.3 & 50 \\
\hline Preserving biodiversity & 33.3 & 33.3 & 50 & 50 & 50 \\
\hline Air pollution & 16.7 & 50 & 33.3 & 33.3 & 33.3 \\
\hline Management approach for emissions: & & & & & \\
\hline i. $\quad \mathrm{GHG} / \mathrm{CO}_{2}$ & 16.7 & 33.3 & 33.3 & 50 & 50 \\
\hline ii. ODS & 0 & 0 & 0 & 0 & 0 \\
\hline iii. Numerical data on gas emission & 0 & 16.7 & 0 & 0 & 0 \\
\hline $\begin{array}{l}\text { Policy to comply with GRI guidelines, GHG Protocol } \\
\text { standard or any other voluntary standards. }\end{array}$ & 33.3 & 50 & 33.3 & 33.3 & 66.7 \\
\hline Tree plantation & 33.3 & 33.3 & 16.7 & 16.7 & 33.3 \\
\hline $\begin{array}{l}\text { Significant impact of activities, products \& services on } \\
\text { Climate change \& global warming }\end{array}$ & 0 & 50 & 50 & 50 & 33.3 \\
\hline $\begin{array}{l}\text { Is there any separate section is devoted to climate } \\
\text { change and/or global warming? }\end{array}$ & 0 & 0 & 0 & 0 & 0 \\
\hline $\begin{array}{l}\text { Do they have any specific board committee related to } \\
\text { environment and/or climate change? }\end{array}$ & 16.7 & 16.7 & 16.7 & 33.3 & 33.3 \\
\hline Compliance with environmental laws and regulations & 50 & 50 & 50 & 50 & 50 \\
\hline Kyoto protocol and/or Paris Agreement & 0 & 0 & 0 & 0 & 0 \\
\hline Average & $22 \%$ & $\mathbf{3 3 . 3 \%}$ & $\mathbf{3 4 . 8 5 \%}$ & $37.1 \%$ & $40.15 \%$ \\
\hline
\end{tabular}




\section{Annexure 4}

A. Number of sentences disclosed by Pharmaceuticals \& Chemical companies in the annual reports

\begin{tabular}{|c|c|c|c|c|c|c|c|}
\hline \multirow[b]{2}{*}{ No. } & \multirow[b]{2}{*}{ Company name } & \multicolumn{6}{|c|}{ Sentences disclosed in the last five years } \\
\hline & & Year-1 & Year-2 & Year-3 & Year-4 & Year-5 & Avg. \\
\hline 1 & $\begin{array}{l}\text { Advanced Chemical Industries (ACI) } \\
\text { Ltd. }\end{array}$ & 28 & 27 & 32 & 30 & 24 & 28 \\
\hline 2 & ACI Formulation Ltd. & 4 & 6 & 9 & 4 & 4 & 5 \\
\hline 3 & The ACME Laboratories Ltd. & 13 & 26 & 34 & 29 & 13 & 23 \\
\hline 4 & Berger Paints Bangladesh Ltd. & 4 & 5 & 10 & 4 & 6 & 6 \\
\hline 5 & BEXIMCO Synthetics Ltd. & 0 & 0 & 0 & 0 & 0 & $\mathbf{0}$ \\
\hline 6 & Marico Bangladesh Ltd. & 5 & 9 & 9 & 29 & 27 & 16 \\
\hline 7 & Reckitt Benckiser (Bd.) Ltd. & 61 & 113 & 76 & 79 & 120 & 90 \\
\hline 8 & Renata Ltd. & 0 & 0 & 0 & 0 & 5 & 1 \\
\hline 9 & FAR Chemical Industries Ltd & 7 & 7 & 7 & 7 & 7 & 7 \\
\hline 10 & AFC Agro Biotech Ltd. & 4 & 4 & 4 & 4 & 3 & 4 \\
\hline 11 & Active Fine Chemicals Ltd. & 0 & 9 & 9 & 10 & 10 & 8 \\
\hline 12 & BEACON Pharmaceuticals Ltd. & 0 & 0 & 0 & 0 & 1 & 0.2 \\
\hline 13 & BEXIMCO Pharmaceuticals Ltd & 5 & 6 & 6 & 17 & 50 & 17 \\
\hline 14 & Central Pharmaceuticals Ltd. & 1 & 1 & 1 & 1 & 1 & 1 \\
\hline 15 & GLOBAL Heavy Chemicals Ltd & 0 & 2 & 2 & 2 & 2 & 2 \\
\hline 16 & $\begin{array}{l}\text { GlaxoSmithKline (GSK) Bangladesh } \\
\text { Ltd. }\end{array}$ & 24 & 21 & 26 & 11 & 15 & 19 \\
\hline 17 & $\begin{array}{l}\text { The IBN SINA Pharmaceutical } \\
\text { Industry Ltd. }\end{array}$ & 4 & 3 & 3 & 21 & 25 & 11 \\
\hline 18 & Imam Button Industries Ltd. & 0 & 0 & 0 & 0 & 0 & $\mathbf{0}$ \\
\hline 19 & Kohinoor Chemical Company Ltd. & 3 & 3 & 9 & 3 & 3 & 4 \\
\hline 20 & Orion Infusion Ltd. & 14 & 37 & 39 & 16 & 20 & 25 \\
\hline 21 & Orion Pharma Ltd. & 2 & 50 & 161 & 144 & 175 & 106 \\
\hline 22 & Pharma Aids Ltd. & 0 & 0 & 0 & 0 & 0 & $\mathbf{0}$ \\
\hline 23 & Salvo Chemical Industries Ltd. & 1 & 1 & 1 & 1 & 1 & 1 \\
\hline 24 & Square Pharmaceuticals Ltd. & 1 & 1 & 1 & 1 & 1 & 1 \\
\hline & & Avera & & & & & 16 \\
\hline
\end{tabular}


B. Number of sentences disclosed by Cement companies in the annual reports

\begin{tabular}{|c|l|c|c|c|c|c|c|}
\hline \multirow{2}{*}{ No. } & \multirow{2}{*}{ Company name } & \multicolumn{5}{|c|}{ Sentences disclosed in the last five years } \\
\cline { 3 - 9 } & & Year-1 & Year-2 & Year-3 & Year-4 & Year-5 & Avg. \\
\hline 1 & MI Cement Factory Ltd. & 7 & 10 & 10 & 10 & 23 & $\mathbf{1 2}$ \\
\hline 2 & Lafarge Surma Cement Ltd. & 47 & 54 & 57 & 49 & 28 & $\mathbf{4 7}$ \\
\hline 3 & Confidence Cement Ltd. & 0 & 0 & 0 & 0 & 0 & $\mathbf{0}$ \\
\hline 4 & Premier Cement Mills Ltd. & 28 & 50 & 54 & 64 & 74 & $\mathbf{5 4}$ \\
\hline 5 & Meghna Cement Mills Ltd. & 1 & 4 & 4 & 16 & 20 & $\mathbf{9}$ \\
\hline 6 & Heidelberg Cement Bangladesh Ltd. & 13 & 48 & 42 & 61 & 25 & $\mathbf{3 8}$ \\
\hline & & \multicolumn{7}{|c|}{ Average } & & & & $\mathbf{2 7}$ \\
\hline
\end{tabular}

\section{Annexure 5}

A. Percentage of the issues disclosed in the last five years by Bangladeshi Pharmaceutical \& Chemical companies

\begin{tabular}{|c|l|c|c|c|c|c|c|}
\hline \multirow{2}{*}{ No. } & \multicolumn{1}{|c|}{ Company name } & \multicolumn{5}{|c|}{ Disclosures in the last five years (\%) } \\
\cline { 3 - 8 } & \multicolumn{1}{|c}{ Year-1 } & Year-2 & Year-3 & Year-4 & Year-5 & Avg. \\
\hline 1 & ACI Formulation Ltd. & 27.3 & 27.3 & 22.7 & 22.7 & 18.2 & $\mathbf{2 3 . 6}$ \\
\hline 2 & The ACME Laboratories Ltd. & 50 & 54.5 & 54.5 & 54.5 & 50 & $\mathbf{5 2 . 7}$ \\
\hline 3 & BEXIMCO Synthetics Ltd. & 0 & 0 & 0 & 0 & 0 & $\mathbf{0}$ \\
\hline 4 & Renata Ltd. & 0 & 0 & 0 & 0 & 9 & $\mathbf{1 . 8}$ \\
\hline 5 & FAR Chemical Industries Ltd & 9 & 9 & 9 & 9 & 9 & $\mathbf{9}$ \\
\hline 6 & AFC Agro Biotech Ltd. & 18.2 & 18.2 & 18.2 & 18.2 & 13.6 & $\mathbf{1 7 . 3}$ \\
\hline 7 & Active Fine Chemicals Ltd. & 0 & 13.6 & 13.6 & 13.6 & 13.6 & $\mathbf{1 0 . 9}$ \\
\hline 8 & BEACON Pharmaceuticals Ltd. & 0 & 0 & 0 & 0 & 4.5 & $\mathbf{0 . 9}$ \\
\hline 9 & BEXIMCO Pharmaceuticals Ltd. & 18.2 & 18.2 & 18.2 & 41 & 59.1 & $\mathbf{3 0 . 9}$ \\
\hline 10 & Central Pharmaceuticals Ltd. & 13.6 & 13.6 & 13.6 & 13.6 & 13.6 & $\mathbf{1 3 . 6}$ \\
\hline 11 & GLOBAL Heavy Chemicals Ltd. & 0 & 4.5 & 4.5 & 4.5 & 4.5 & $\mathbf{3 . 6}$ \\
\hline 12 & $\begin{array}{l}\text { The IBN SINA Pharmaceutical } \\
\text { Industry Ltd. }\end{array}$ & 18.2 & 13.6 & 13.6 & 41 & 31.8 & $\mathbf{2 3 . 6}$ \\
\hline 13 & Imam Button Industries Ltd. & 0 & 0 & 0 & 0 & 0 & $\mathbf{0}$ \\
\hline 14 & Kohinoor Chemical Company Ltd. & 13.6 & 13.6 & 31.8 & 13.6 & 13.6 & $\mathbf{1 7 . 2}$ \\
\hline 15 & Orion Infusion Ltd. & 27.3 & 31.8 & 31.8 & 22.7 & 27.3 & $\mathbf{2 8 . 2}$ \\
\hline
\end{tabular}




\begin{tabular}{|c|l|c|c|c|c|c|c|}
\hline 16 & Orion Pharma Ltd. & 13.6 & 41 & 59.1 & 59.1 & 63.6 & $\mathbf{4 7 . 3}$ \\
\hline 17 & Pharma Aids Ltd. & 0 & 0 & 0 & 0 & 0 & $\mathbf{0}$ \\
\hline 18 & Salvo Chemical Industries Ltd. & 4.5 & 4.5 & 4.5 & 4.5 & 4.5 & $\mathbf{4 . 5}$ \\
\hline 19 & Square Pharmaceuticals Ltd. & 13.6 & 13.6 & 13.6 & 13.6 & 13.6 & $\mathbf{1 3 . 6}$ \\
\hline & \multicolumn{7}{|c|}{ Average } \\
\hline
\end{tabular}

B. Percentage of the issues disclosed in the last five years by MNC Pharmaceutical \& Chemical companies

\begin{tabular}{|c|l|c|c|c|c|c|c|}
\hline \multirow{2}{*}{ No. } & \multicolumn{1}{|c|}{ Company name } & \multicolumn{5}{c|}{ Disclosures in the last five years (\%) } \\
\cline { 3 - 10 } & \multicolumn{1}{|c|}{ Year-1 } & Year-2 & Year-3 & Year-4 & Year-5 & Avg. \\
\hline 1 & $\begin{array}{l}\text { Advanced Chemical Industries } \\
\text { (ACI) Ltd. }\end{array}$ & 36.4 & 31.8 & 31.8 & 31.8 & 31.8 & $\mathbf{3 2 . 7}$ \\
\hline 2 & Berger Paints Bangladesh Ltd. & 18.2 & 22.7 & 18.2 & 18.2 & 22.7 & $\mathbf{2 0}$ \\
\hline 3 & Marico Bangladesh Ltd. & 22.7 & 36.4 & 36.4 & 31.8 & 36.4 & $\mathbf{3 2 . 7}$ \\
\hline 4 & Reckitt Benckiser (Bd.) Ltd. & 41 & 54.5 & 50 & 50 & 50 & $\mathbf{4 9}$ \\
\hline 5 & $\begin{array}{l}\text { GlaxoSmithKline } \\
\text { Bangladesh Ltd. }\end{array}$ & 13.6 & 27.3 & 22.7 & 9 & 18.2 & $\mathbf{1 8 . 2}$ \\
\hline
\end{tabular}

\section{ANNEXURE 6}

A. Percentage of the issues disclosed in the last five years by Bangladeshi Cement companies

\begin{tabular}{|c|c|c|c|c|c|c|c|}
\hline \multirow[b]{2}{*}{ No. } & \multirow[b]{2}{*}{ Company name } & \multicolumn{6}{|c|}{ Disclosures in the last five years (\%) } \\
\hline & & Year-1 & Year-2 & Year-3 & Year-4 & Year-5 & Avg. \\
\hline 1 & MI Cement Factory Ltd. & 9 & 22.7 & 22.7 & 18.2 & 18.2 & 18.2 \\
\hline 2 & Confidence Cement Ltd. & 0 & 0 & 0 & 0 & 0 & $\mathbf{0}$ \\
\hline 3 & Premier Cement Mills Ltd. & 41 & 59.1 & 68.2 & 72.7 & 72.7 & 62.7 \\
\hline 4 & Meghna Cement Mills Ltd. & 4.5 & 9 & 9 & 27.3 & 36.4 & 17.2 \\
\hline & \multicolumn{6}{|c|}{ Average } & $24.5 \%$ \\
\hline
\end{tabular}




\section{Macrothink \\ International Journal of Accounting and Financial Reporting ISSN 2162-3082 2020, Vol. 10, No. 4}

B. Percentage of the issues disclosed in the last five years by MNC Cement companies

\begin{tabular}{|c|c|c|c|c|c|c|c|}
\hline \multirow[b]{2}{*}{ No. } & \multirow[b]{2}{*}{ Company name } & \multicolumn{6}{|c|}{ Disclosures in the last five years (\%) } \\
\hline & & Year-1 & Year-2 & Year-3 & Year-4 & Year-5 & Avg. \\
\hline 1 & Lafarge Surma Cement Ltd. & 41 & 41 & 45.5 & 41 & 59.1 & 45.5 \\
\hline \multirow[t]{2}{*}{2} & $\begin{array}{l}\text { Heidelberg Cement Bangladesh } \\
\text { Ltd. }\end{array}$ & 36.4 & 68.2 & 63.6 & 63.6 & 54.5 & 57.3 \\
\hline & \multicolumn{6}{|c|}{ Average } & $51.4 \%$ \\
\hline
\end{tabular}

\section{Copyright Disclaimer}

Copyright for this article is retained by the author(s), with first publication rights granted to the journal.

This is an open-access article distributed under the terms and conditions of the Creative Commons Attribution license (http://creativecommons.org/licenses/by/4.0/) 